Article

\title{
Analysis of Social Responsibility and Reporting Methods of Romanian Companies in the Countries of the European Union
}

\author{
Marian Socoliuc ${ }^{1, *}$, Veronica Grosu ${ }^{1}$, Elena Hlaciuc ${ }^{1}$ and Silvius Stanciu ${ }^{2} \mathbb{C}$ \\ 1 Department of Accounting, Audit and Finance, "Stefan cel Mare" University, 720229 Suceava, Romania; \\ doruveronica@yahoo.it (V.G.); elenah@seap.usv.ro (E.H.) \\ 2 Department of General Sciences, “Dunărea de Jos” University, 800008 Galati, Romania; sstanciu@ugal.ro \\ * Correspondence: marians@seap.usv.ro; Tel.: +40-740027973
}

Received: 30 September 2018; Accepted: 5 December 2018; Published: 7 December 2018

check for updates

\begin{abstract}
In the context of the current economy, the concept of corporate social responsibility has gained momentum, and its significance derives from the attitude of companies that have understood the importance of the impact of their activity on the environment in which they conduct their operations. The present study emphasizes the fact that CSR has an equal importance for those companies of varying sizes that operate in developing countries, such as Romania. There are still a lot of challenges regarding their implementation. The study focuses on establishing the level of CSR report by the Romanian companies within the European Union framework by taking into account the extent to which they are familiar with the CSR reporting guidelines in order to identify the degree of applying the Global Reporting Guidelines (GRI) when designing the sustainability reports. The data regarding the acceptance of the voluntary report and its correlation to the sustainable development as a strategic focus of the management of entities, the usefulness, the necessity and the obstacles of voluntary reporting were gathered based on a questionnaire. Between 2015-2017, 61 Romanian companies of various sizes had to answer specific questions. The research is based on the descriptive statistics as well as the correlation analysis method. The findings of the research proved that the acceptance of the management in terms of the sustainable development is in a close relationship with implementing voluntary reporting and the willingness to develop a favorable image of the company within a competitive market. The study also identified the differences that exist between a company's success on the market that is linked to their development and the economic factors that characterize each and every field of activity. The present study focuses on defining the term 'social responsibility' from the point of view of its concepts. It also aims at presenting the social responsibility reporting methods used by the companies from the European Union countries. These can be a starting point for those companies that have not had the chance of applying them yet.
\end{abstract}

Keywords: social responsibility; voluntary reporting; integrated reporting; sustainability

\section{Introduction}

In the current economic context, the term 'corporate social responsibility' is being used to an increasing degree, in particular by large companies that invest consistently in CSR programs and aim at integrating CSR in each and every sector of their business. Corporate social responsibility is no longer just a topic discussed in the literature but it has been taken up in practice by companies and implies several obligations: ethical behavior, social dialogue with stakeholders, economic, social, and environmental performance, and sustainable development. Currently, corporate social responsibility is an important requirement for company development, as it offers many advantages in terms of differentiation, in an increasingly competitive environment. 
In developed countries, companies have understood the importance of CSR for their business strategy and at the same time, the importance of stakeholder engagement in their business, as the later become more and more interested in the moral behavior of companies. Within the present-day context of an increasing globalization, the growth of the international transactions and the development of the corporate phenomena through enhancing the presence of the multinational companies as emerging entities, the traditional financial reporting models are not tailored face the challenges of disclosing all the significant facets that lead to adequate CSR and the sustainable development forecasting capacity needed by companies. Thus, one can state that the traditional financial reporting no longer meets all the information needs of the stakeholders [1], and the solution comes from the companies in the form of voluntary reports on corporate social responsibility. There are several models developed by European and international bodies that address the social and environmental dimensions of a company's business.

In EU countries, the challenge resides in encouraging businesses to look at social responsibility as being something beyond a simple marketing strategy designed to improve their image, i.e., seeing it as an important element in achieving long-term success, ensuring sustainability and implementing social and environmental performance concepts for the community and society in general.

After interpreting the questionnaire applied to Romanian entities, it can be noticed that economic entities tend to change their perception and attitude towards the environment in which they are operating. The goals set by entities are no longer focused exclusively on the economic aspects, but they take into account the social and environmental goals as well [2]. It is important that entities have understood their impact on the environment in which they operate and that they place more and more emphasis on issues such as social equity, working conditions, environmental prevention and preservation, health and safety, with over $50 \%$ of the respondents wishing to implement the social balance and over $36 \%$ wishing to implement the environmental balance, while about $14 \%$ are interested in reporting other additional information on the reporting of intangible assets. The mode that companies feel and behave towards the environment been recognized as a significant cause of difficulty in implementing innovation strategy [3]. These elements are specific to the concept of social responsibility.

As a result of the pressure applied by a wide range of users of financial and non-financial information, concepts such as social reporting, environmental reporting, sustainability reporting, or integrated reporting have been increasingly used by companies. As a result, the number of these reports has increased considerably by becoming the core of the business itself detrimental to traditional financial reports [4]. A number of European and international bodies have been involved in developing guidelines, standards, regulations, and models in relation to corporate social responsibility reporting, approach as a complementary way to provide social, environmental, or financial information to interested stakeholders.

Yet, the question that arises is what would be the issue of CSR in a developing country such as Romania. In spite of the fact that during the recent decades an increasing number of studies have focused on CSR issues in developing countries [5-7], less attention has been paid to the role that local regulations and the activism of the organizations played in promoting transparency, accountability, and responsible business practices.

The pressures made by the stakeholders on the companies have determined the latter to take on certain social, environmental, and financial responsibilities, and an increasing number of stakeholder's request information on the performance of entities from these three perspectives. In this context, traditional financial reporting does not provide a complete picture or sufficient information on the economic, social, and environmental performance of an entity, which led, over time, to the preparation of other types of reports that meet the information needs of the users.

The present study attempts at filling the existing information gap by addressing the extent of the control exercised by local regulation and national NGO activism on the nature of corporate social businesses disclosure in a developing country, namely Romania. The present study is a contribution to the debate on governance, transparency, accountability, and CRS in the industrial sector, the marketing of consumer goods and services. The last section of the present study is based on the analysis of the content of social responsibility and sustainability reports that were published by local companies 
as well as by foreign companies in different fields of activity, including the information presented on their official websites in order to identify those elements related to social responsibility and its communication tools. Secondly, based on this analysis, we suggested a standard model of social responsibility reports for the Romanian micro-enterprises.

The present study focuses on the analysis of the way companies in the field of industry, the marketing of consumer goods and services in Romania are able to take on voluntary reporting, so they are more transparent towards their stakeholders and, most importantly, to emphasize the connection that exists between this type of reporting and the sustainable development. Thus, by analyzing the content of the social responsibility reports and the official websites, our goal is to design a standard model of social responsibility report for micro-enterprises in Romania. The study's goal is, on the one hand, to define the 'social responsibility term' through the concepts it represent and, on the other hand, to present the social responsibility reporting methods of the companies within the European Union. This could represent a starting point for those companies that have not put them into practice yet. The present study analyses the way companies conduct business in the industrial sector, the marketing of goods and services in Romania, their acceptance of the voluntary reporting process, the transparency of the stakeholders and, most importantly, the connection between this type of reporting and the sustainable development. The research gap that will be addressed by the present study is to find answers to a series of issues including:

- The manager's agreement on sustainable disclosure is closely linked to the acceptance of the phenomenon and the planning methods of implementing the financial reports with voluntary disclosure.

- The restraints in using the voluntary disclosure are closely linked to the acceptance both of the phenomenon and the economic sectors involved in the voluntary disclosure.

- The main reasons for voluntary disclosure mainly refer to the foresight aspects of the development strategy. They offer an attractive image of the company are related to a sustainable development.

From this point of view, a questionnaire was addressed to 61 entities in Romania. It aimed at achieving four main goals such as: the availability of the entities and their acceptance of the voluntary reporting which would be the underlying reasons for implementing this type of reporting; the extent to which the financial accounting information is a relevant source of information in sustaining such reporting; identifying the main indicator structures that provide relevant information on an economic entity yet not sufficient to fully meet the stakeholders' requirements and the management that seeks support for sustainable development policies. As an example, we have analyzed within the following section of the present study both the content of the social responsibility and sustainability reports that were published by local companies, as well as some companies operating abroad in several fields of activity. We also analyzed the information presented on their official websites in order to identify those elements related to social responsibility and its communication tools.

The present study focuses on the recent data of the synthesis presenting the conclusions of a meta-analysis regarding the connection of the CSR with the social, macroeconomic, branch, or business concepts (aimed at combining performance, company image, and capital accumulation, as well as focusing on the differences by quantifying the risks that threaten the business economy). These associations serve as the foundation in presenting a complex picture of the implementation of CSR interest, manifested throughout time (mid-term analysis, namely 20 years). They are the basis for designing of a regionally adapted profile (Romania's case) and updated for a voluntary disclosure, a concept that has been increasingly viewed as a performance generator, in addition to the notoriety function usually performed by voluntary reporting.

The study is structured into five sections. The next section offers a theoretical framework that helps develop assumptions that will be tested, as well as a review of the literature on the connection between corporate investment in CSR and the company's performance. In this respect, for a clearer vision of the concepts we will resort to the structuring of meta-analysis on related phenomena based on the technique of dissociation phenomena, the existing correlation between CSR and concepts such 
as size effect, size of the industry tournament prize, corporate governance, executive compensation, equity grants, managerial slack, financial performance, corporate financial performance, sustainable livelihood framework, multiple stakeholders dialogue, consumer responses, HR, cross-listed firms, occupational health and safety, firm's product quality, community social capital, firm value prevailing on the post of significance. The third section sets out the research methodology of our study including the data sources, the means that were used, and the details of the performed analysis. In this section, we have suggested a standard model of social responsibility report for the Romanian micro-enterprises. The fourth section presents the outcome of the study. The study ends with a conclusion of the findings of the study, as well as observations on their limitations.

We believe that the present research is useful for the management of those economic entities that seek to optimize their economic and financial communication through additional information that has a key role in attracting new investors and in maintaining an elevated level of performance, sustainable development, and awareness of the importance of social responsibility.

The overall methodology and the measures to be taken are shown below.

\section{Literature Review}

\subsection{Theoretical Framework}

In order to fully understand the complexity linked to the CSR reporting, researchers have designed several theoretical frameworks such as stakeholders, legitimacy, institutional frameworks, and political economy, which have ensured the comprehension of the social and environmental issues connected with corporate activities [8].

Over the past decades, CSR has evolved from a narrow and often marginalized concept to a complex and multifaceted one by playing a central role in the business decision-making process nowadays [9]. It has become a try autonomous discipline that is characterized by a variety of methodological approaches and theoretical orientations that often mingle together or are significantly divergent.

The concept of CSR is to be found in business ethics studies, corporate citizenship, sustainable development, and fair trade. There are numerous CSR applications in various aspects of a company. However, in spite of the fact that the company's ethical dimension is fully accepted, there is still no consensus on its nature. The existence of various meanings of CSR are often the results of the organization's point of view in terms of boundaries such as: moral obligation, reputation and sustainability instrument, businessman's reputation, and therefore, the license to function. Votaw states that "corporate social responsibility means something but not always the same for everyone" [10].

Over the time, research studies have focused, on the one hand, on defining the concept of CSR and its ethical foundation [11,12]. This lead to numerous theories, methods, and terms [13], and on the other hand, on the search for the potential business rationale for CSR and its related effects in terms of economic and financial reputation and performance [13,14].

In order to consolidate the CSR's perception of the international experts, we conducted a meta-analysis of the research in the field. The meta-analysis is extended throughout a 20-year period aims at studying CSR in relation with concepts and theories on the impact of corporate governance, compensation and social capital, group financial performance, incentives, and directions that have been discussed by experts in studies that are relevant to the present phenomenon.

The benchmarks envisaged when compiling the meta-analysis were based on the selection of research papers indexed in Web of Science and which had CSR and corporate governance as topics.

The reason for choosing these works was the research field and the notoriety of research journals. Thus, we only chose the works published in top journals and whose design research was focused on keywords like CSR, firm value, and corporate governance.

The results of the study are shown in the Table 1 : 
Table 1. Meta-analysis on CSR and related issues.

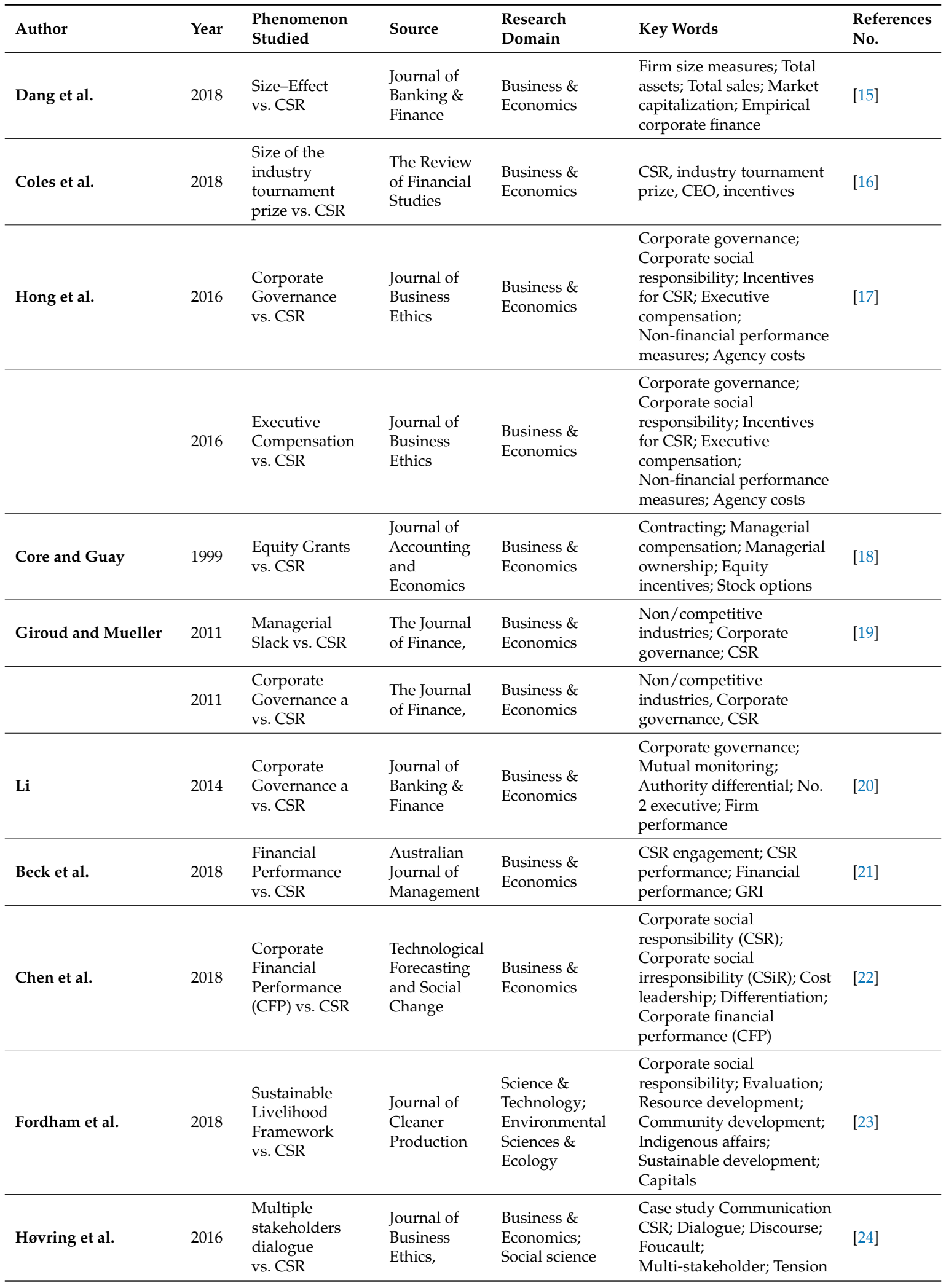


Table 1. Cont.

\begin{tabular}{|c|c|c|c|c|c|c|}
\hline Author & Year & $\begin{array}{l}\text { Phenomenon } \\
\text { Studied }\end{array}$ & Source & $\begin{array}{l}\text { Research } \\
\text { Domain }\end{array}$ & Key Words & $\begin{array}{l}\text { References } \\
\text { No. }\end{array}$ \\
\hline Lee et al. & 2018 & $\begin{array}{l}\text { Consumer } \\
\text { Responses } \\
\text { vs. CSR }\end{array}$ & $\begin{array}{l}\text { Fashion and } \\
\text { Textiles }\end{array}$ & $\begin{array}{l}\text { Material } \\
\text { Sciences }\end{array}$ & $\begin{array}{l}\text { California Transparency in } \\
\text { Supply Chains Act; Socially } \\
\text { responsible consumption; } \\
\text { Consumer response; } \\
\text { Website; Experiment }\end{array}$ & [25] \\
\hline Reimsbach et al. & 2018 & $\begin{array}{l}\text { Corporate } \\
\text { Financial } \\
\text { Performance } \\
(\mathrm{CFP}) \text { vs. CSR }\end{array}$ & $\begin{array}{l}\text { Journal of } \\
\text { Cleaner } \\
\text { Production }\end{array}$ & $\begin{array}{l}\text { Business \& } \\
\text { Economics } \\
\text { Social } \\
\text { Sciences-Other } \\
\text { Topics }\end{array}$ & $\begin{array}{l}\text { Corporate social } \\
\text { responsibility (CSR) } \\
\text { reporting; CSR } \\
\text { performance; Political } \\
\text { embeddedness; } \\
\text { Government control; } \\
\text { Political connections }\end{array}$ & [27] \\
\hline Shi et al. & 2018 & $\begin{array}{l}\text { Cross-Listed } \\
\text { Firms vs. CSR } \\
\text { Performance }\end{array}$ & $\begin{array}{l}\text { Frontiers of } \\
\text { Business } \\
\text { Research in } \\
\text { China }\end{array}$ & Business & $\begin{array}{l}\text { Corporate social } \\
\text { responsibility (CSR); } \\
\text { Cross-listing; Bonding; } \\
\text { Emerging markets; } \\
\text { Corporate governance; } \\
\text { Institutional CSR; CRS } \\
\text { performance; Technical CRS }\end{array}$ & [28] \\
\hline Tsalis et al. & 2018 & $\begin{array}{l}\text { OHS } \\
\text { (Occupational } \\
\text { Health and } \\
\text { Safety) }\end{array}$ & $\begin{array}{l}\text { Safety } \\
\text { Science }\end{array}$ & $\begin{array}{l}\text { Operations } \\
\text { Research \& } \\
\text { Management } \\
\text { Science }\end{array}$ & $\begin{array}{l}\text { Corporate social } \\
\text { responsibility reporting; } \\
\text { Benchmarking-scoring } \\
\text { techniques; Sustainability } \\
\text { reports } \\
\text { Global reporting initiative }\end{array}$ & [29] \\
\hline Hoi et al. & 2016 & $\begin{array}{l}\text { Community } \\
\text { Social Capital } \\
\text { vs. CSR }\end{array}$ & $\begin{array}{l}\text { Journal of } \\
\text { Business } \\
\text { Ethics }\end{array}$ & $\begin{array}{l}\text { Business \& } \\
\text { Economics } \\
\text { Social } \\
\text { Sciences-Other } \\
\text { Topics }\end{array}$ & $\begin{array}{l}\text { Corporate social } \\
\text { responsibility; Social } \\
\text { capital; Social norm }\end{array}$ & [31] \\
\hline Buchanan et al. & 2018 & $\begin{array}{l}\text { Company Value } \\
\text { vs. CSR }\end{array}$ & $\begin{array}{l}\text { Journal of } \\
\text { Corporate } \\
\text { Finance }\end{array}$ & $\begin{array}{l}\text { Business \& } \\
\text { Economics }\end{array}$ & $\begin{array}{l}\text { Corporate social } \\
\text { responsibility; ESG; Firm } \\
\text { value; Corporate } \\
\text { governance; Financial } \\
\text { crisis; }\end{array}$ & \\
\hline
\end{tabular}

Source: [15-32].

From the author's opinion, the most representative correlations were made in terms of those among corporate governance, corporate financial performance, or image building, on the one hand, and corporate social responsibility concepts, on the other hand. The representation of the powerful impact on the analyzed phenomena is presented in Figure 1. 


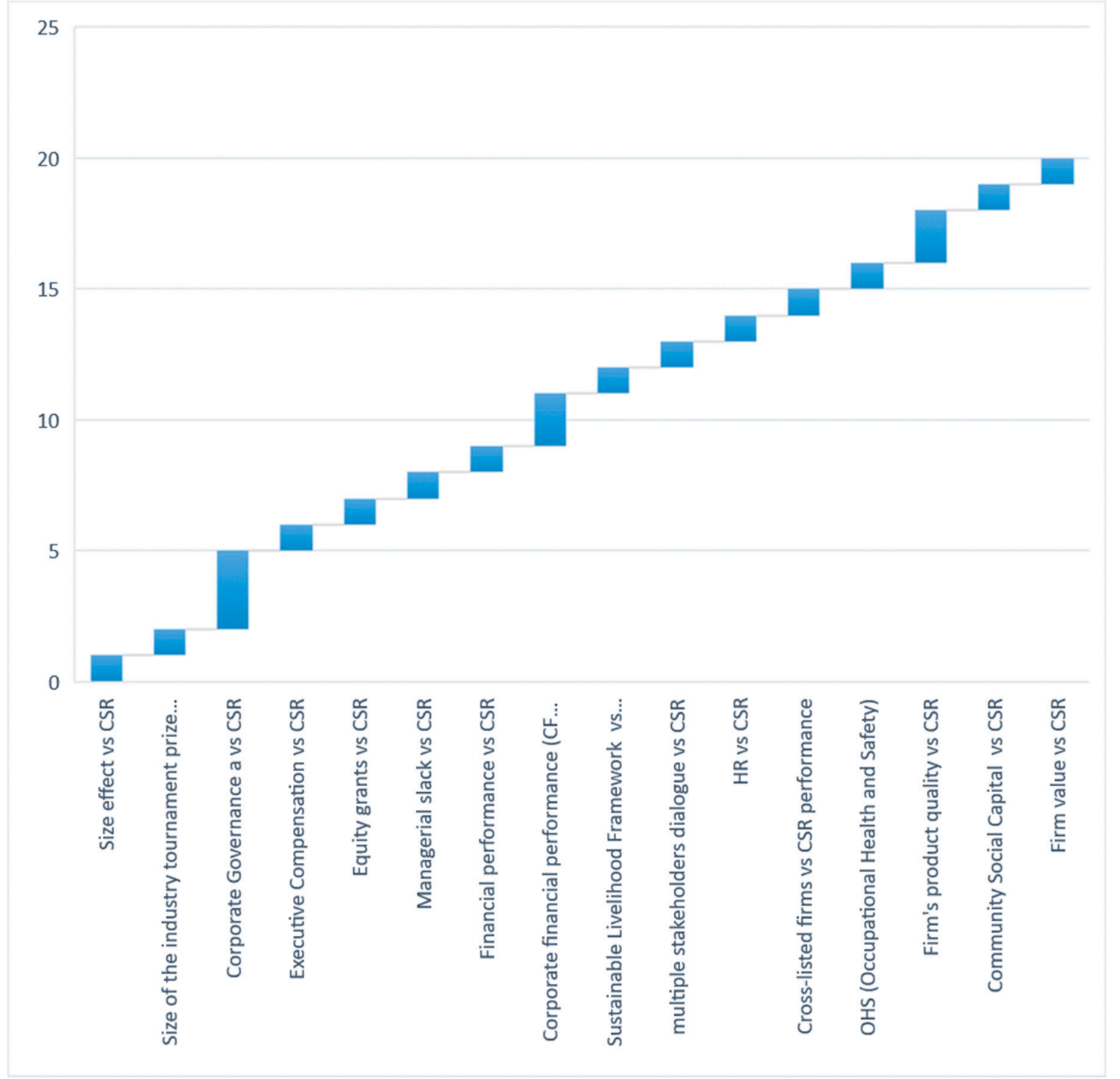

Figure 1. Grid of CSR Perceptions-Observations of International Experts on CSR Regarding Economic Theories and Concepts; Source [15-32].

Hong A's study [17], highlights the fact that bringing managers to companies who are concerned about corporate social responsibility is a meaningful way of boosting social performance. Using this element as a starting point, the study reveals the fact that those respondents in leadership positions, especially in small and medium-sized companies, are concerned with the implementation of CSR in their company because they are aware that. Thus, they will be able to increase their company's social performance and its long-term sustainability.

Another point of interest was the correlation between corporate financial performance (CFP) and CSR [27]. In this respect, Chen et al. [22], believes that cost management and differentiation strategies can positively mitigate the relationship between CSR and CFP. It can negatively weaken the relationship between CSiR (corporate social irresponsibility) and CFP, too. Companies with higher levels of social performance may be more able to synergize the added value and value creation associated with CSR projects to enhance business performance. In this respect, respondents consider that social performance is a component of the entity's overall performance. 
Another area in which opinions were expressed is the one that refers to creating a perspective with regard to consumer behavior, the increase of the quantity delivered by the company, and CSR [25].

In this respect, the study conducted by Calveras and Ganuza [30] highlighted the fact that high-quality hotel establishments are indeed more likely to be socially responsible both internally and externally. This indicates the existence of complementarity, which derives from their relationship with the quality of the product. From this point of view, the entities that are involved outside the entity in projects that have a social responsibility component are more involved in internal initiatives that have a social component, such as the training of the employees.

Coles et al. [16] concludes that there is a causal link between CEO incentives in industry tournaments, which can substantially explain the performance, risk, investment policy, and financial policy of the companies.

Hong [17] discusses the concepts of corporate governance and executive compensation for corporate social responsibility. The study reveals that companies that have a large portfolio of shareholders and are focused on corporate governance are those who will be able to reward their executives as a result of the results achieved in the field of social performance. The study highlights the fact that CSR depends on the size of the entity, the independence of board boards, a limited number of owners within it, low financial performance, and high social performance.

Core and Guay [18] in the article "The Use of Equity Grants to Manage Optimal Equity Incentive Levels" analyzes a positive connection among the portfolio capital incentives, the opportunities for development as well as the sustainability of the entity management.

Giroud and Mueller [30] evaluates CSR studied the concepts of corporate governance, product market competition, and equity prices. The authors show that a weak corporate governance entity has low incomes, a lower operating performance and a low business value solely within uncompetitive industries. They also have a decreased labor productivity and higher production costs and make more purchases that do not add value to the entity.

Beck [21] addresses the CSR disclosure from the point of view of the financial performance (the cross-country analysis). The authors point out that employing CSR can be an indication of the current CSR performance. Therefore, CSR implementation at the entity level reflects the CSR performance of the entity's overall performance. Larger CSR engagement scores are statistically associated with a larger business size.

Fordham [23] in "The Sustainable Livelihood Framework as a Means of Linking Corporate Social Responsibility to Community Benefit" points out that getting a level of capital required at a strategic level demands strategic approaches based on a collaborative relationship in regards to CSR, either through internal programs of the entities or through resources for the external stakeholders.

Høvring, [24] in "Discursive Tensions in CSR Multi-stakeholder Dialogue" argues that a multiparty perspective contributes to the complexity of the dialogue with CSR stakeholders which manifests itself in different formats and nuances by ranging from a pure idealistic notion of equality and solidarity to realistic antithesis, thus marking a global tension between an ideal idea and a realistic conviction of the stakeholders' dialogue in CSR.

Obara and Peartie [26] show that, for most companies, CSR has been a significant educational field in the past. It has influenced the development and management of human resources within companies. The CSR was definitely a 'framework' of the organization (as it retained the knowledge and the 'memory' of the organization) that manifested itself when companies took HR into consideration and the way these engagements were then organized and implemented.

Shi et al. [28] highlights the positive association of improvement efforts within the market share of entities. The improvement of CSR is more obvious for companies with poor corporate governance. 
Tsalis et al. [29], assesses the quality of CSR in relation to OHS by pointing out that the factors influencing the quality of OHS reporting practices refer to the industrial sector, the continent in which companies operate and the OHSAS certification. Companies are more familiar with this SSM topic and the usage of measurement mechanisms to monitor the progress of their performance over the years. In fact, by reducing personal injury rates, companies promote a good OHS profile and improve their reputation.

Hoi [31], through the CSS vs. CSR analysis, concludes that companies undertake several positive CSR activities when such activities are more widespread among other local corporations that operate in the same county.

There is also no systematic relationship between negative CSR activities and the community involvement in negative CSR activities.

Positive CSR activities increase the future financial performance of a company whereas the positive effect is more visible among companies based in counties with an increased community capital.

Buchanan [32] points out that community social capital promotes CSR and moderates the CFP-CSR relationship. The effect of CSR on a company's value varies depending on the level of influential institutional property. It is closely connected with economic conditions.

Compared to non-CSR firms, CSR companies have an increased value before a financial crisis, yet there have seen more losses in regards to a company's value during the crisis.

A point of interest within the present topic is discussed in Dang's article [15] entitled "Observations on the Size of a Company and CSR" which is in itself a meta-analysis of the phenomenon. The correlations presented in the article are briefly described in the Figure 2.

As it can be seen in the chart below, the total assets are more relevant for the executive compensation, the internal company diversification, the capital structure and the investment policy, instead of the performance, and the associated risk. The size refers to the total resources from which the company can generate profit.

In terms of total sales, the study shows that they are more important for the dividend policy, cash holdings, and not so much for the diversification of investments, or for mergers and acquisitions.

In terms of market capitalization, it is positively influenced by the risk, the capital's structure, the investment and the mergers and acquisitions, but not the ones destined for corporate governance.

The size of the company is positively influenced by the mergers and acquisitions, the company's diversification, and the corporate finance. It is negatively influenced by the dividend policy, the executive compensation, and the capital's structure. 


\section{total assets}

-+ executive compensation

$\bullet+$ firm diversification

-+ capital structure

$\bullet+$ investment policy

- firm performance

- risk

\section{total sales matters more for}

$\bullet+$ dividend policy

- cash holdings

- investment diversification

- $M \& A$

\section{market capitalisation}

-+ firm risk

-+ capital structure

$\bullet+$ investment

- M\&A

-+forward looking

- + ownership of equity

$\bullet+$ control for the size in stock market

- corporate governance.

\section{size measures}

\section{$\bullet+M \& A$}

-+ firm diversification

-+ corporate finance

- dividend policy

- executive compensation

- capital structure

Figure 2. Size effect vs. CSR. Source: Interpretation of the authors according to Dang [15].

Analyzing the authors' interest over time, corporate governance in relation to CSR has been an interest for researchers for more than a decade. It manifested itself in numerous articles and studies that have proved that corporate governance is a trigger for CSR. For a better clarification of the concepts, we used the structuring of meta-analysis on related phenomena using the dissociation technique of the phenomena as significance, with the foreground correlation between CSR and concepts such as: size effect, size of the industry tournament prize, corporate governance, executive compensation, equity grants, managerial slack, financial performance, corporate financial performance, sustainable livelihood framework, multiple stakeholders dialogue, consumer responses, HR, cross-listed firms, occupational health and safety, firm's product quality, community social capital, and firm value (see Figure 3). 


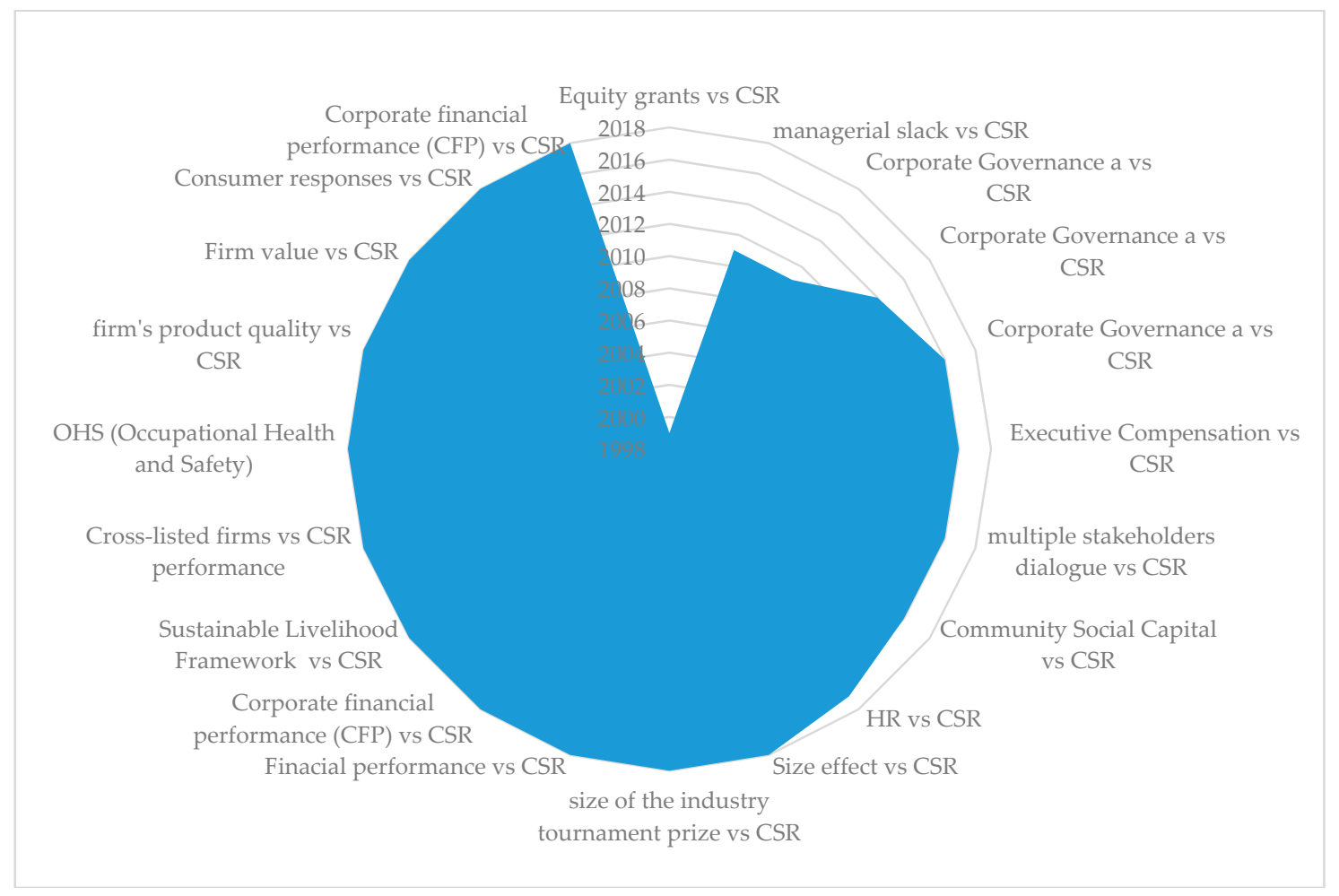

Figure 3. The evolution in time of CSR approach.

Lately, from 1998 to 2018, CSR approaches have been amplified in relation to several concepts, which clearly indicate that CSR implementation is a necessity for the global economy.

An economic entity that has an internal policy based on social responsibility and sustainable development is more likely to have a positive perception on the part of the community, as well as new opportunities to motivate social actors and to strengthen its image on the market, and will therefore succeed in gaining the confidence of stakeholders. The role of the company is to strike a balance between its internal operations and the external image it projects, through its activity and through various programmers that would help it meet its own needs, but also those of different stakeholder categories [33].

Debate regarding the relationship between society and business have carry on for a long time, and these debates have spread to the topics of CSR. In the 1960s and 1970s, the main question for explorers was "what should management do for society?" [34].

In 1953 Bowen makes a change in regards to the terminology used in defining the present phenomenon by offering his first broad contribution in defining a social consciousness of the businessman. Later on, the concept has been detailed by Carrol in 1979. The author gives the next definition: "The social responsibility of business encompasses the economic, legal, ethical and discretionary expectation that society has of organizations at a given point in time" [11].

It is very relevant to realize how the internal members of a company levy the companies' activities and performance, as employees' perceptions of the company will affect their position and comportment, which will eventually have an influence on both personal and organizational performance [35].

The majority of the definitions on corporate social responsibility refer to it as a concept whereby "companies integrate social and environmental interferences in their business operations and in their interaction with their stakeholders on a voluntary basis" [36,37]. Hart defines CSR as "the company's considerations of and response to issues above the narrow economic, technical and legal requirements of the company to accomplish social [and environmental] benefits alongside with the traditional economic benefits which the company seeks to achieve" [38]. 


\subsection{The Relationship That Exists between CSR Dimensions and the Company's Value/Financial Performance/Operational Inefficiency/Corporate}

Over the last four decades, more than 150 studies have been published investigating the relationship that exists between the corporate social responsibility and the company value. Some authors concluded that this relationship would be one of the most elaborate business and management research [39]. However, some conclusions were ambiguous and even contradictory compared to the previous studies in the sense that some researchers discovered the existence of a positive association between the two dimensions [40,41], whereas others identified a negative association [42] or no relationship at all [33] between the two dimensions.

In order to support the scientists, McWilliams and Siegel highlighted the risk of omitting those variables that were important determinants of the financial performance, such as R\&D investment, the accuracy of the results [43]. At the same time, they signaled the significant theoretical limitations and empirical studies that may affect the already existing ones. The author demonstrates the fact that in the event the model is appropriately designed to include research and development intensity, CSR has a neutral impact on the financial performance. In order to better understand this aspect, a series of thorough reviews have been carried out over time by using meta-analytical approaches [44,45].

Coenenber et al. [46] believes that the role of corporate reports is to provide relevant information in order to facilitate decision-making as a foundation for determining the total value of the entity.

As CSR activities are followed by supplementary corporate costs, not every CSR activity drive to a remarkable outcome $[47,48]$. There is ongoing academic interest in establish which economic benefits and drawbacks ensue from corporate participation in socially responsible activities [49]. Much of the studies on CSR have targeted the connection between CSR and corporate financial performance [50,51]. Orlitzky et al. [45] lead a meta-analysis of 52 major research and reported limited positive (+) relationships between CSR and financial performance. Pursuant to a meta-analysis of empirical researches on CSR performance and corporate financial performance by Margolis et al. [39], overall, the relationships between them were statistically limited, but positive. More precisely the analyzed studies reported a positive (e.g., [52]), negative (e.g., [39]), and null (e.g., [53]) relationship. Such combined effects conducted to questions about whether a company's social activity can be lightly, fixed based on their financial performance.

Some authors $[54,55]$, in response to critical comments, considered it imperative to create an integration model for measuring and managing corporate sustainability in order to use the synergistic effects of selected stochastic variability (SV) and economic added value (EAV), models with benchmarking support that can become a safe tool for assessing and managing the Czech manufacturing firm. The definition given by Lozano et al. explains the fact that corporate sustainability is emphasized by the theory of sustainability oriented corporate: "The company is a profit generating entity in a state of constant evolution" [55].

The investment in corporate social responsibility initiatives is both a source of competitive advantage and a tool for assessing the financial performance [56,57]. Taking into account the informational discrepancy between the company and its shareholders, the investment in leading companies develops and consolidates the trust of the stakeholder in the company by 'indicating' the way it honors its obligations and the possibility of fulfilling the expectations of several actors, thus providing guidance on its future behavior [58] when using CSR activities as a means to report those features that seem interesting to the stakeholders [59].

A different research trend investigates CSR within the operational inefficiency as complimentary to the socio-financial performance relationship.

Guillamon et al. using the data envelopment analysis (DEA) notes that less dynamic inefficiency manifests itself in those companies that are more committed to the CSR activities. They are negatively related to the involvement of companies in the CSR social and corporate governance, yet positively associated with the ecological aspect of CSR [60]. 
Taking into account the slow progress of the public recognition of this new communication means and the data availability of a wide range of corporations, the obstacles underpinning this process refer primarily to the absence of analytical models to speed up the data analysis and to actually generate the evaluation results that enable for systematic and objective comparisons among several types of CSR reports. When examining the CSR reports of 48 of the world's largest mining corporations based on an analytical structure called CSR-Sustainability Monitor, Sethi et al. demonstrated the fact that the CSR reports of these companies provide extensive information on major environmental, social, and governance issues [61].

The optimum relationship with the shareholders is directly related to the sustainable development and CSR. From this point of view, there are numerous studies [62-64] that are characterized by:

- Fundamental business activity over a long period of time, overcoming the obstacles and divergences in getting economic results from both the internal and external system, the involvement of the board of directors in supporting the sustainability objectives;

- Creating the opinion that sustaining the sustainability objects represents and ensures the essence of CSR's evolution as an integrated goal of business operations.

CSR management is considered by many authors from the point of view of the institutional theories based on which organizations adapt themselves to the existing pressures in the institutional environment in order to survive and continue their activity. The idea of CSR strategic management that supports CSR sovereignty and management was also promoted by Lankoski in 2016 [65].

\section{Research Methods}

Sustainable development issues are closely linked to the ability of companies for intelligently report so that their users, including entities management, have at their disposal qualitative financial information on which they can then develop reliable strategies in the spirit of sustainable development. Given that economic activity is the engine of national and European economies as a whole, the principles of sustainable development apply directly to the economic entities and must be implemented based on a policy package elaborated on the basis of quality accounting information that allows the bodies to evaluate the state of their implementation.

In this context, the aspects of voluntary reporting that represent an area of interest for the International Accounting Standards Board (IASB) acquires significant valence in relation to the proposed field of research.

During 2015-2017, the authors conducted a questionnaire addressed to a number of 61 Romanian economic entities active in the industrial sector, the marketing of consumer goods and services, regarding the acceptance, utility, necessity, and impediments of voluntary reporting whose results will be disseminating in the future.

The analyzed group of companies is made up of 61 Romanian companies which were selected based on:

(a) Size (micro-enterprise, small enterprise, average enterprise, large enterprise);

(b) Fields of activity (financial and non-financial services, short-term and long-term consumer goods, low-tech and high-tech industrial goods);

(c) The analyzed indicators: turnover, number of employees, added value, operating result, depreciation expense, financial result, net result, carried over, total assets, equity, short-term liabilities, long-term liabilities, provisions (correlations between the turnover growth index, the number of employees, and the net result).

The majority of these entities are active in the trade and service sectors. They are at different (onset, development, or maturity) stages of development. The respondents of the questionnaire were the managers or chief accountants engaged in the reporting work or accounting experts from the accountancy companies that prepared the financial reports for these entities. 
The authors made initial contact with them and afterwards sent the questionnaire to those who agreed to respond to it.

The companies were selected on the basis of their size according to the legislative amendments of the Romanian accounting regulations having in view the transposition of Decision 34 of the EEC.

The questionnaire was made both of closed (yes/no) questions and open questions. The respondents were also asked to fill in the company's economic and financial data.

The questionnaire was structured on four sections and a total of 88 questions, with eight or fewer variants:

- Section 1-Acceptance of disclosure;

- Section 2-Reasons, usefulness and impediments to reporting;

- Section 3-Financial-accounting information;

- Section 4-Entity structure indicators.

\subsection{Section 1-Acceptance of Disclosure}

A set of 13 questions were use on the expression of the pros and cons of supplementary financial accounting reports. In addition, the entities are asking about:

- The option to supplement the management report;

- The future application of voluntary disclosure to firms not currently using this tool with specification of future milestones planning, if any;

- Opinions on important sections of voluntary disclosure as perceived by the entity and areas covered by voluntary disclosure according to respondents' appreciation;

- Assessment of the contribution of voluntary disclosure;

- The opportunity for further disclosure through a financial analysis report to supplement the situation annual financial and, last but not last, the opinion of the entities on the exchange of experience and the setting up of good practices on voluntary disclosure.

Regarding the availability of voluntary reporting entities, a relatively balanced distribution of it were found in that a $52.46 \%$ majority of entities demonstrated the availability of additional financial reporting, while $47.54 \%$ were against (Figure 4 ).

Regarding the supplementation of the management report, the opinion of the entities is much more reserved, being unfavorable in the percentage of $50.82 \%$, plus a $4.92 \%$ abstinence, which denotes that the management of the entities considers that only the supplementation of the management is insufficient to optimize voluntary reporting and that they agree in the future with $55 \%$ additional voluntary reporting, but among the surveyed respondents, over $85 \%$ did not take concrete steps to plan the disclosure voluntary (Figure 5).

In this respect, our study highlighted the fact that the managers of the surveyed entities are interested in improving the voluntary reporting by including $40.98 \%$ in the integrated voluntary reporting of the environmental balance and $34.43 \%$ in the social balance and only one percentage point reduced by almost $2 \%$ from a sustainability report (Figure 6 ).

A very high percentage of respondents $(88.52 \%)$ do not know the field that should be involved in voluntary reporting (Figure 7) and, moreover, they are aware of the benefits of voluntary reporting but have not quantified to date the contribution that voluntary reporting could bring to the sustainable development of the entities in the future $(67.21 \%)$, with $29.51 \%$ are those who quantified the contribution of the voluntary reporting and only an insignificant percentage of the firms surveyed (2 out of 62) did not respond in this regard (Figure 8). 


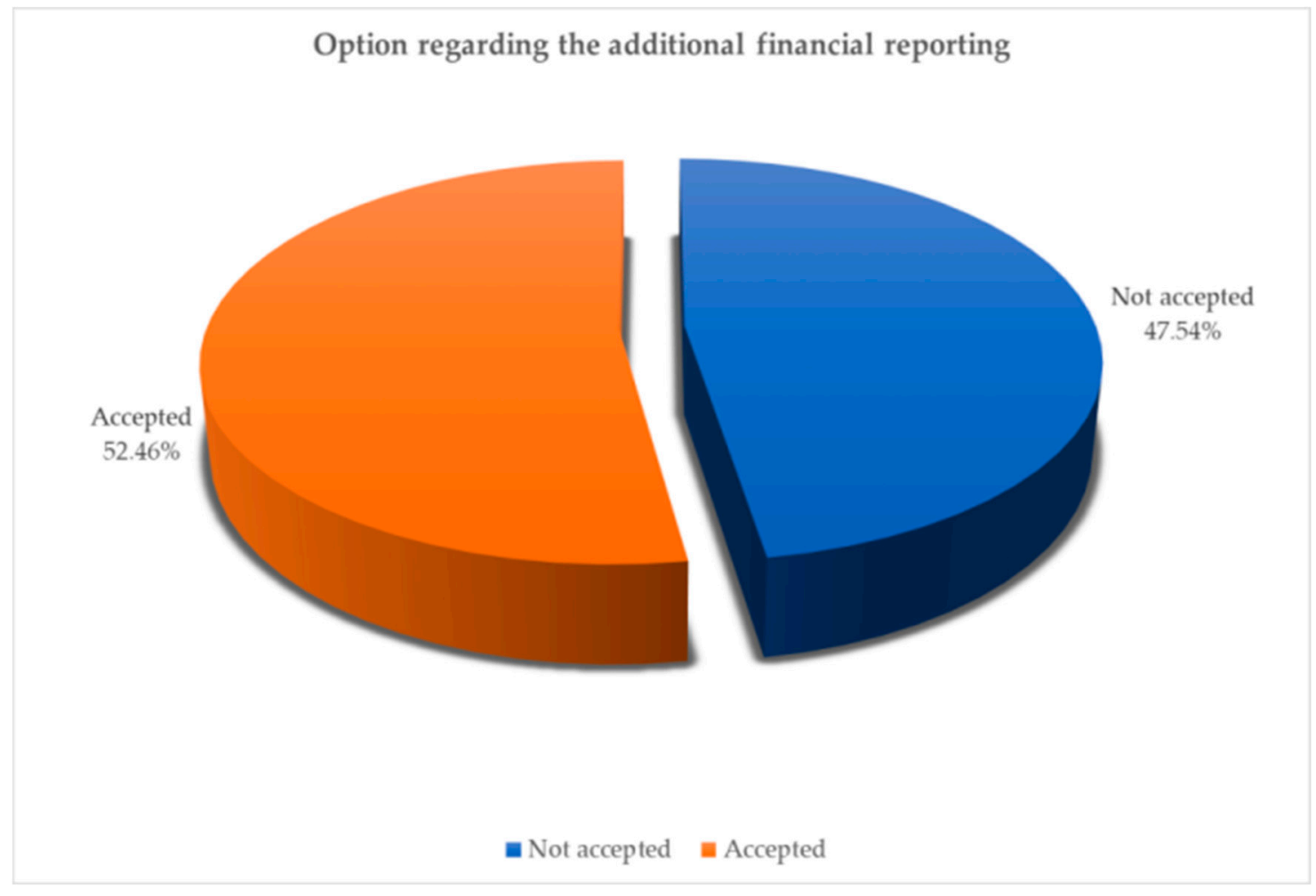

Figure 4. Option regarding the additional financial reporting.

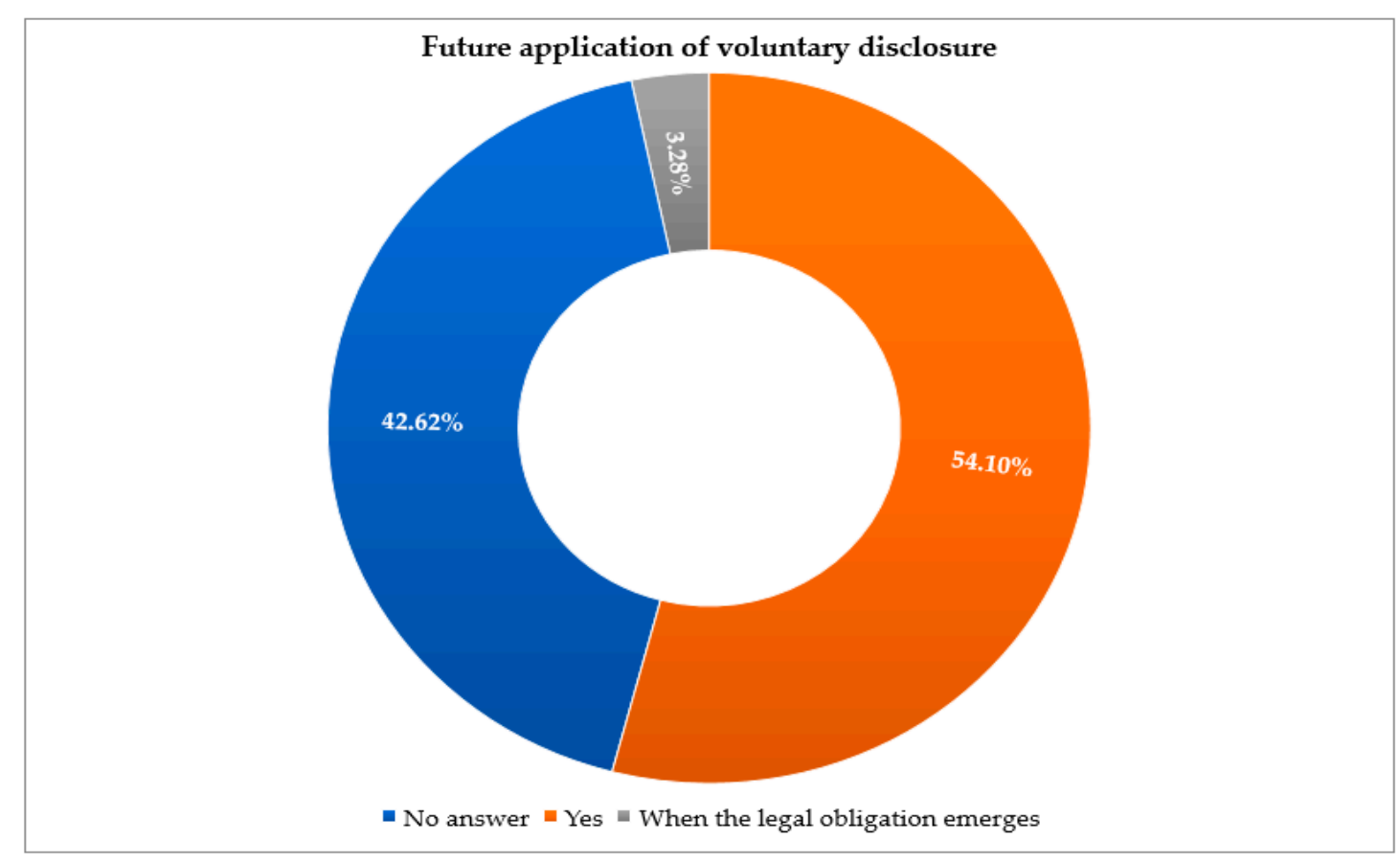

Figure 5. Future application of voluntary disclosure. 


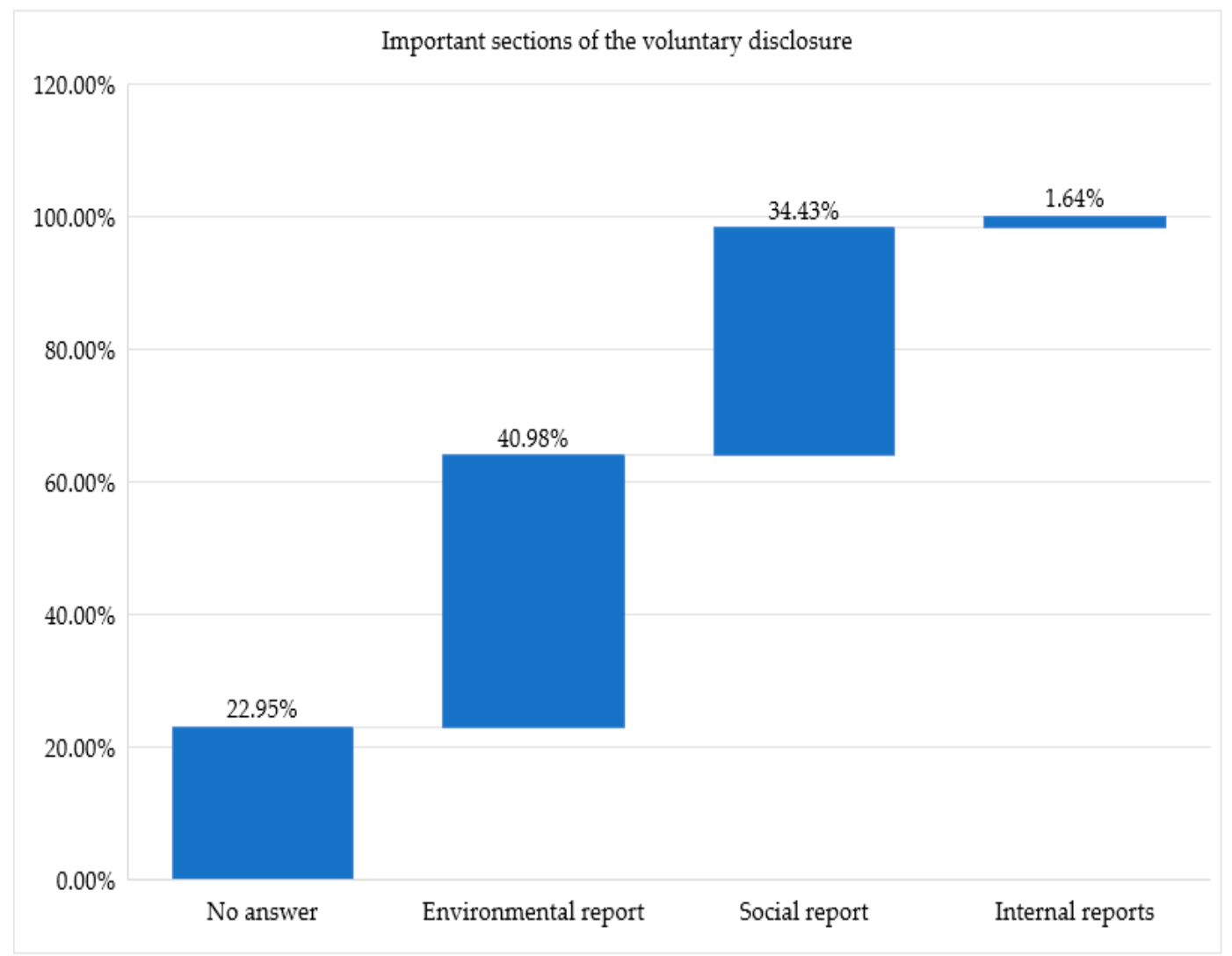

Figure 6. Important sections of the voluntary disclosure.

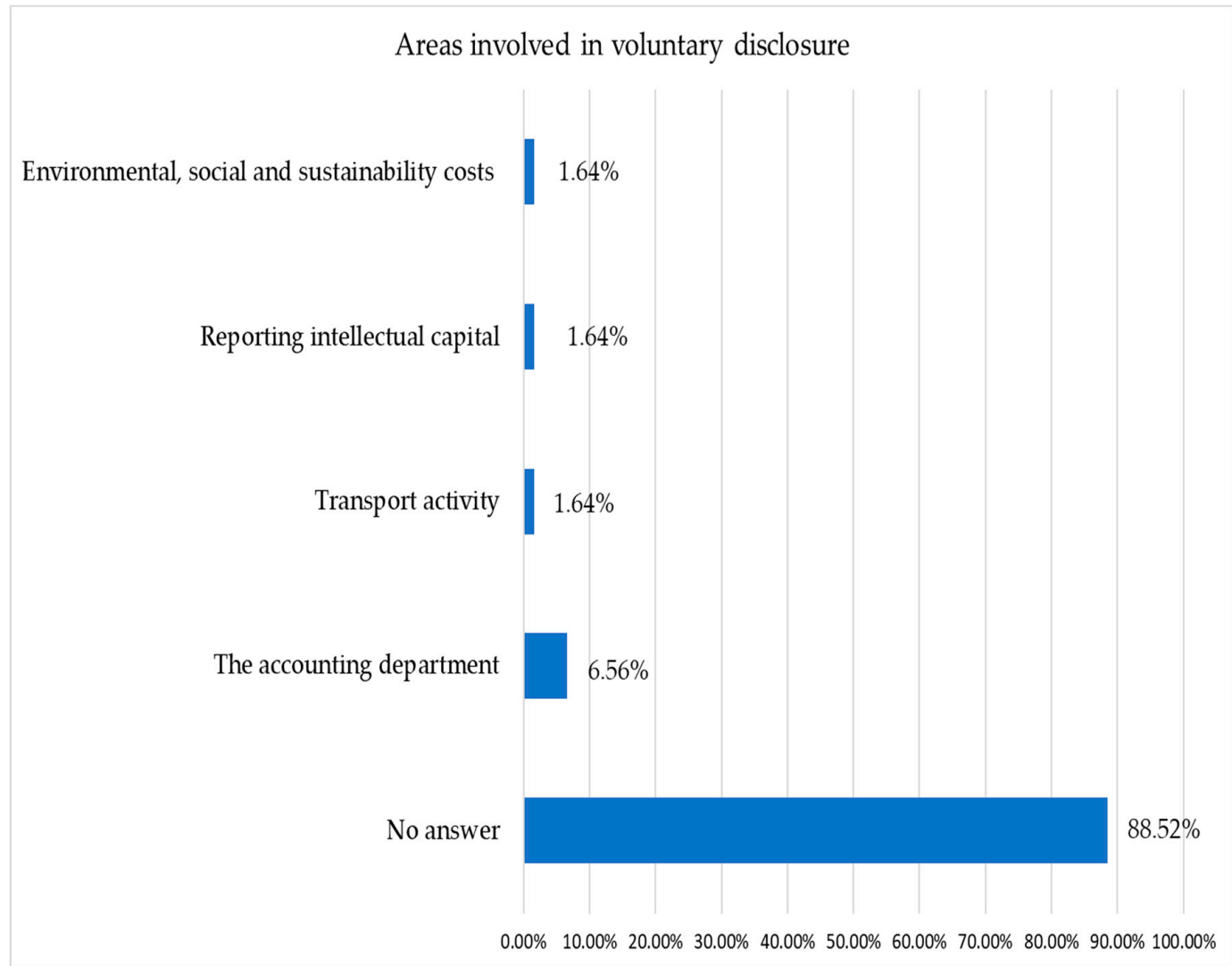

Figure 7. Areas involved in voluntary disclosure. 


\section{ACCEPTING EXPERIENCE EXCHANGES REGARDING VOLUNTARY DISCLOSURE}

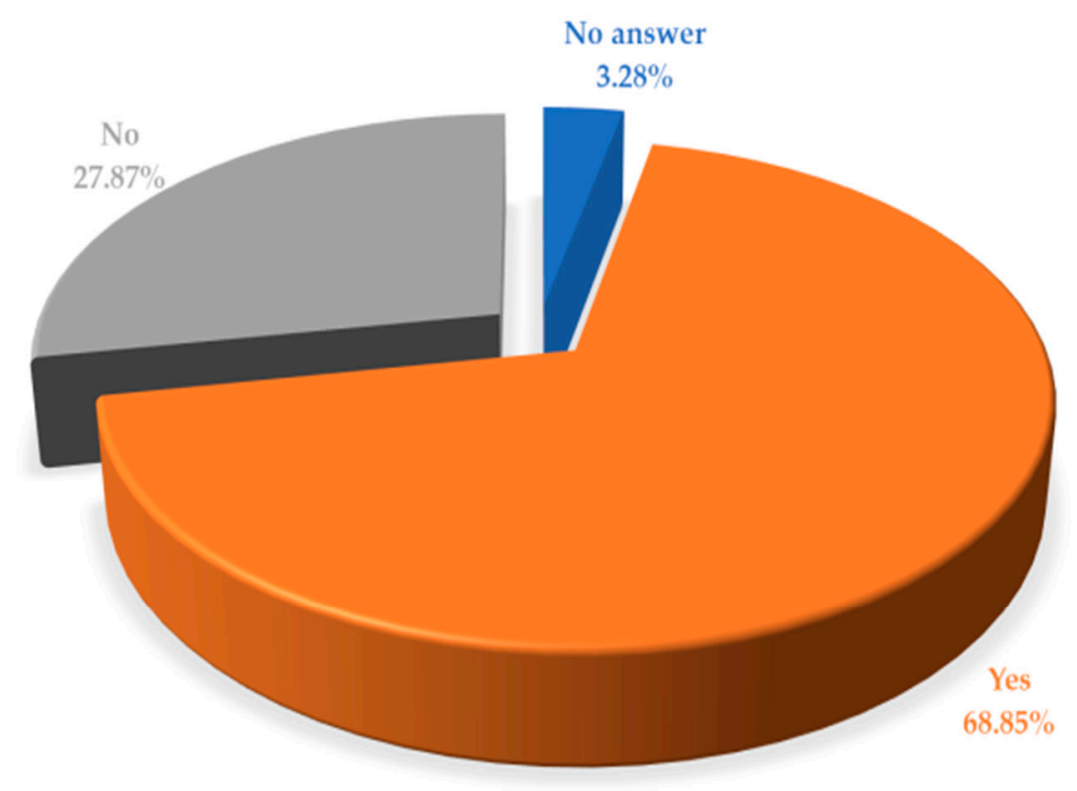

Figure 8. Accepting experience exchanges regarding voluntary disclosure.

Regarding the opportunity to disclose the financial analysis report in addition to the traditional balance sheet, $55.74 \%$ of the surveyed companies agree with this $39.34 \%$ disagree with this and 3 out of 61 entities did not respond to this item. The respondents are generally aware of the benefits of the voluntary reporting. In particular, they should be provided with more information on environmental spending [66], social spending by setting up an equilibrium in this respect, together with valuating and reporting of tangible assets that are not part of the traditional reporting [67]. Yet, they do have the knowledge of how they can put these regulations into practice. The study also shows that, in the future, they are concerned with improving voluntary communication and implementing reports. Among the entities that responded affirmatively to the previous item, regarding the opportunity to disclose the financial analysis report supplementary to the traditional balance sheet, the entities responded to this item at $63.33 \%$ and $26.67 \%$ of them considered that this aspect would lead to a sustainable development of entities in the future. From our point of view, there is obviously a tendency towards a culture of sustainable reporting of the entities in Suceava City, but this percentage of more than a quarter of the entities is still insufficient. We believe that the trend is clear to an increase in the level of information to the managers of the entity of the undeniable benefits that voluntary reporting can bring to the sustainable development of entities.

Also, among the surveyed entities, almost $51 \%$ did not provide answers to the significant aspects that the disclosure of the financial analysis report was additional to that of the traditional balance sheet. A percentage of $23 \%$ of the entities believe that attracting new investors would lead to an expansion of activity and $11.50 \%$ believe that they will attract new funding resources. More than $82 \%$ of respondents believe that in the future the practice of voluntary disclosure will expand a lot and about $70 \%$ of them would agree to borrow good practices and exchange experiences with entities where voluntary reporting is already certain. 
Regarding the opinion on voluntary disclosure, the most significant percentage of respondents $(49.18 \%)$ did not provide answers on this issue, followed by the fact that entities consider that information transparency of the rapports is needed (Figure 9).

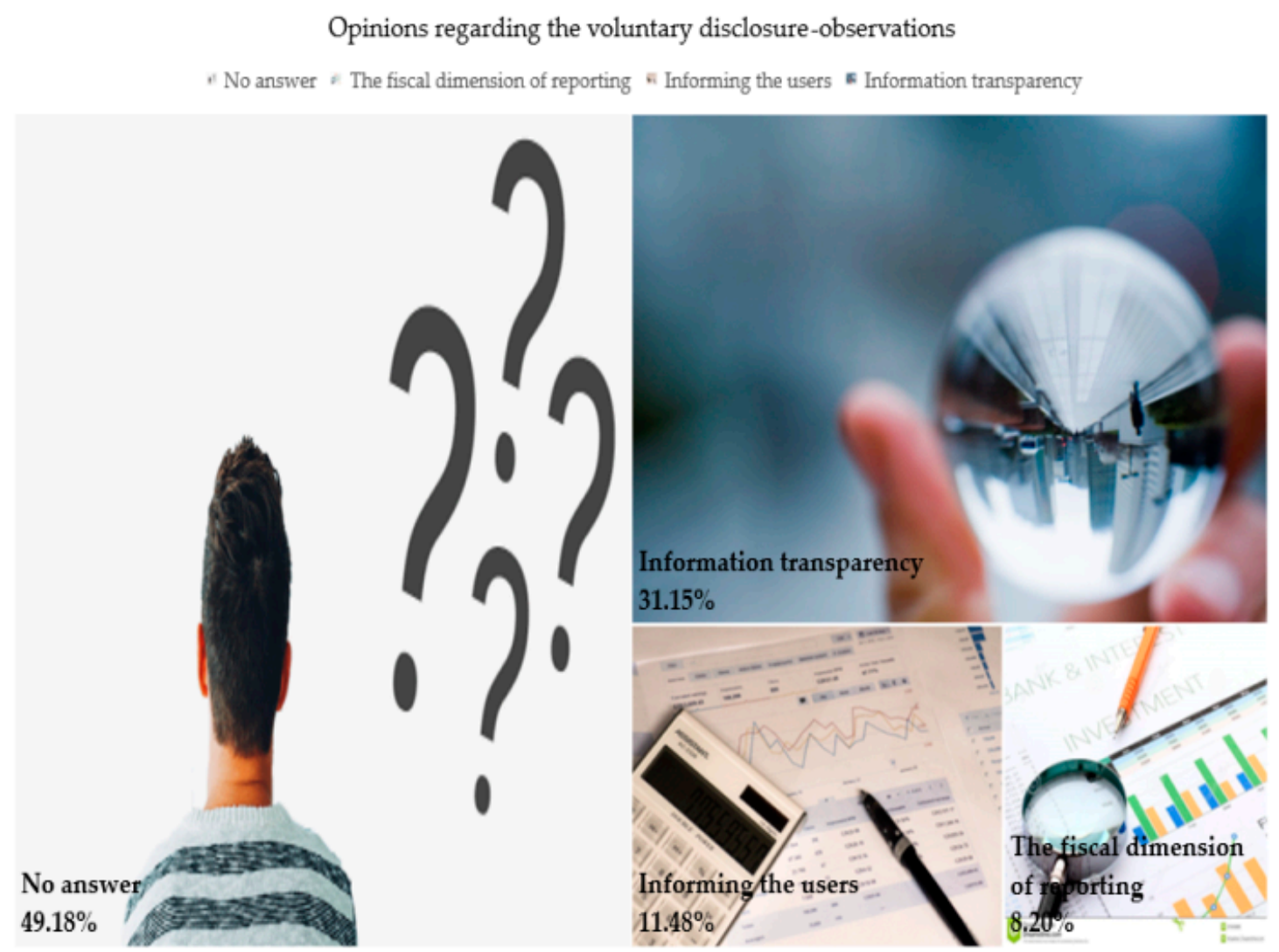

Figure 9. Opinions regarding the voluntary disclosure-observations.

The study also highlighted the fact that voluntary disclosure is also necessary due to the fiscal dimension of reporting. This is due to the interdependence between accounting and taxation in the sense that the main user of accounting information in the financial statements of Romanian entities is the state. Thus, traditional Romanian reports serve the fiscal needs of the state to the detriment of the other stakeholders. The study focused on the fact that in spite of the fact that the Romanian entities are tributaries to the state in terms of financial reporting, most of them are aware of the fact that within a globalized economy, a sustainable development of entities can be achieved only by overcoming the limits that are imposed by the traditional reporting and by activating a voluntary reporting which mitigates the boundaries of the mandatory one.

\subsection{Section 2-Reasons, Utility, and Impediments of Reporting}

A set of 17 questions was used to follow reasons, utility, and impediments of reporting. From the analysis of the respondents' answers, it was noticed that they did not provide motivated responses to additional voluntary reporting $(68.85 \%)$ and among the entities that represented the most significant percentage they considered that a supplementary disclosure would lead to an increase in the information transparency and an improvement in managerial decisions (Figure 10). 


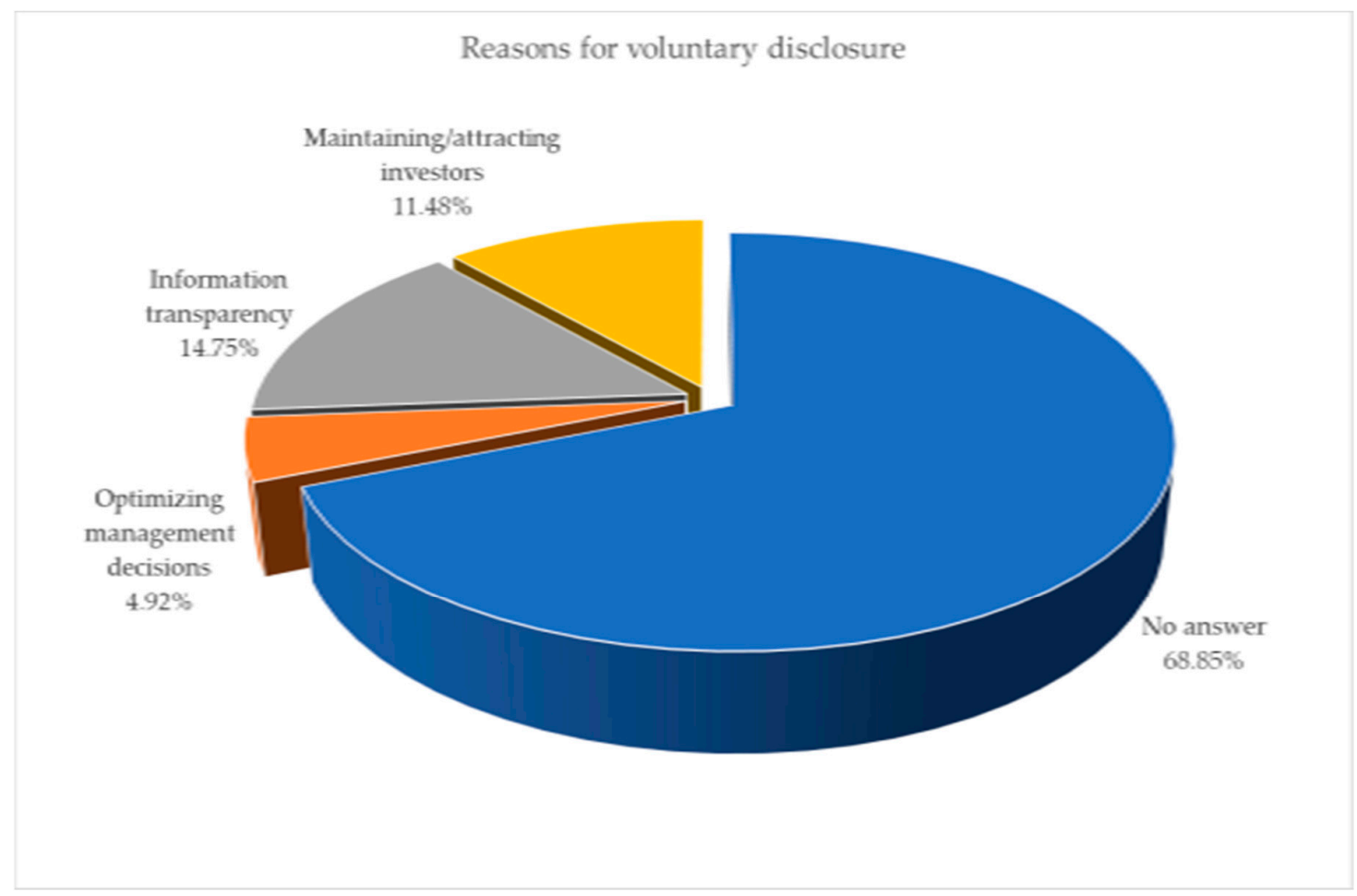

Figure 10. Reasons for voluntary disclosure.

This again reveals that managers have understood that they can improve their management decisions based on feed-back received from users as a result of additional information provided to them. They also believe that the main impediments to voluntary disclosure are lack of time, prudence, and the sufficiency of the information already provided.

Regarding the assessment of the contribution of the voluntary disclosure, the respondents believe that the main issue would be related to the alignment of the exploitation management activity with the strategic objectives $(34.43 \%)$ as well as the increase of the profitability of the invested capital.

Regarding the impact of voluntary disclosure on the qualitative characteristics of accounting information, the study highlighted that by increasing disclosure, accounting information will be accurate $(44.26 \%)$ and at the same time will be relevant (37.70\%), more understandable $(14.75 \%)$, clearer for users, and the decisions taken will also take into account the fiscal component. For business partners an increase in informational disclosure, meaning an additional information, will lead to managerial decisions taken on the basis of relevant and accurately represented information (Figure 11). Investors and shareholders want the information to be primarily understandable, but also relevant and represented exactly to the same extent.

\begin{tabular}{|c|c|c|c|}
\hline $\begin{array}{l}\text { Qualitative features of } \\
\text { the information } \\
\text { obtained through } \\
\text { voluntary disclosure }\end{array}$ & $\begin{array}{l}\text { Significant aspects } \\
\text { for business } \\
\text { partners }\end{array}$ & $\begin{array}{l}\text { Signficant aspects } \\
\text { for investors/ } \\
\text { shareholders }\end{array}$ & $\begin{array}{l}\text { Significant aspects } \\
\text { for long term } \\
\text { creditors }\end{array}$ \\
\hline No answer & $11.48 \%$ & $13.33 \%$ & $23.73 \%$ \\
\hline relevance & $60.66 \%$ & $30.00 \%$ & $20.34 \%$ \\
\hline exact representation & $18.03 \%$ & $25.00 \%$ & $28.81 \%$ \\
\hline intelligibility & $9.84 \%$ & $31.67 \%$ & $27.12 \%$ \\
\hline
\end{tabular}

Figure 11. Qualitative features of the information obtained through voluntary disclosure. 
For long-term creditors, additional disclosure leads to an accurate representation of financial accounting information, which is considered to be useful in the long-term lending decisions.

Regarding the regulatory opacity introduced by current Romanian accounting regulations, the present study emphasized the fact that by adopting them we are witnessing a tendency to increase the quality of disclosure given by the new division of entities (micro-entities, small entities, medium entities, and large entities) as well as simplifying reports with a significant impact on the times and costs associated with reporting work. Entities questioned revealed the fact that in the current context of accounting reporting a separation of the operating result from the exceptional result is necessary, as well as the need for the reporting system to differentiate the entity's book value from market value due to the presence of unrecognized and unrated assets in traditional financial reporting. This latter aspect leads to the need to identify alternative assessment and reporting methods.

\subsection{Section 3-Financial-Accounting Information}

In this section, a total of 50 questions were used on the main stakeholders surveyed by stakeholders.

The survey highlighted that, as for the turnover evolution index, this has increased by $16.8 \%$, indicating that additional reporting of the information has led to an increase in turnover, as in the case of large entities at we have noticed a constant sales turnover from one year to the next. In small entities, the study pointed out that turnover fluctuates a lot and that they are very volatile from one period to the next. Regarding the average of the evolution of the number of employees, the research showed that there was an increase in the number of employees by $7.61 \%$ which we can corroborate with the growth of the turnover index. In the case of the net result, it can be seen that firms reporting supplementary accounting information recorded a higher average evolution over the other group.

\subsection{Section 4-Entity Structure Indicators}

The study has highlighted that the current structure of the annual financial statements favors micro-entities and small entities by simplifying the type of reporting, and with regard to medium and large entities they are willing to call to voluntary disclosure to fill the gap in mandatory reporting. The study highlighted the fact that the entities that reported additional information were those that are on the upward trend in terms of development and that the growth rate of turnover was in line with the development rate of the exploitation activity.

According to a survey prepared by KPMG in 2015, 73\% of the N100 companies (the largest 100 companies in each country including Romania) perform social responsibility reporting, a slight increase compared to 2013 (71\%). Chart no. 1 illustrates the upward trend in social responsibility reporting, which started in 1999 with $24 \%$ and reached its peak in 2015. The percentage of corporate social responsibility reporting for G250 companies (the largest company based on the revenue according to Fortune 500 ) reaches $92 \%$, a fairly high percentage, although it has been on a downward trend since 2011 when it reached a maximum of 95\%. Figure 12 highlights the upward trend from 1999 to 2015 for the two variables, which emphasizes the increased interest of companies in social responsibility and its reporting [68]. 


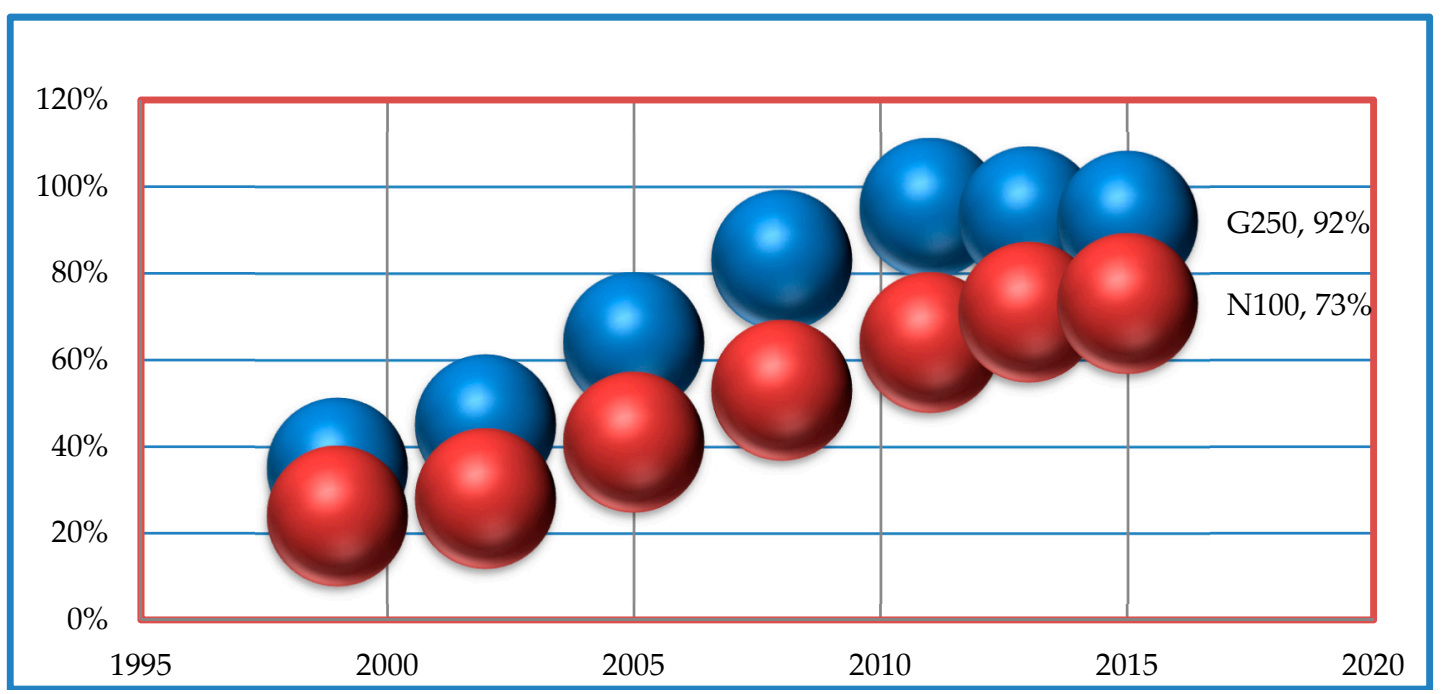

Figure 12. Evolution of social responsibility reporting. Source: Adapted from KPMG-Survey of Corporate Responsibility Reporting, 2015 [68].

The Global Reporting Initiative (GRI) has conducted the most advanced sustainability reporting activity. GRI was established in 1997 at the initiative of CERES (the Coalition for Environmentally Responsible Economies), an American organization, and its goal was to prepare a complete information mechanism aimed at all the stakeholder (multi-stakeholders), rather than just at investors, as CERES had done so far [69]. There are several versions that have been developed, the first one appeared in 2000 and the latest version was issued in 2018, GRI 102. Compared to the other versions, G4 (current GRI 102) places more emphasis on the need to direct the report towards the most relevant topics as to the entity's activities and main stakeholders [70]. The previous standard G4 'Guidelines' included two parts [71]: reporting principles and disclosure of standard information, that include reporting principles, standard information, and the criteria that an organization must apply to prepare the sustainability report in accordance with the guidelines. It also includes the definitions of key terms; the Implementation Manual contains explanations on how to apply the reporting principles, how to prepare the information to be reported and how to interpret the concepts in the "Guidelines". Unlike GRI, 2013 in the current version of GRI (2018) the principles of sustainable reporting must include the following criteria (Table 2):

Table 2. Structure of the GRI 102: General Disclosures.

\begin{tabular}{cc}
\hline General Information & Specific Information \\
\hline Organization profile & \\
Strategy & Management Approaches (DMA); \\
Ethics and Integrity & Performance indicators ranked according to the three dimensions: \\
Governance & economic, social and environmental; \\
$\begin{array}{c}\text { Stakeholder engagement } \\
\text { Reporting practice }\end{array}$ \\
\hline Source: Adapted from "Consolidated Set of GRI Sustainability Reporting Standards", 2018, p. 23 [70].
\end{tabular}

The sustainability report can be prepared in two versions, which are both compliant with G4, namely: Core-A simpler, smaller version and Comprehensive-A much more detailed version [71]. Each version can be adopted by any company, depending on its size, field of activity, or location. In terms of sustainability reporting principles, they are divided into two categories, as follows (Table 3): 
Table 3. Reporting Principles.

\begin{tabular}{|c|c|}
\hline Report Content Principles & Report Quality Principles \\
\hline $\begin{array}{l}\text { Stakeholder engagement: organizations must identify } \\
\text { their stakeholders and explain how they respond to } \\
\text { their expectations and interests; }\end{array}$ & $\begin{array}{l}\text { Balance: The report should reflect the positive and } \\
\text { negative aspects of the organization's performance, } \\
\text { in order to determine a grounded assessment of the } \\
\text { overall performance; }\end{array}$ \\
\hline $\begin{array}{l}\text { Sustainability: the report should outline how the } \\
\text { organization has achieved performance in the } \\
\text { economic, social, and environmental dimensions; }\end{array}$ & $\begin{array}{l}\text { Comparability: The information must be presented in } \\
\text { such a way as to ensure that an analysis is conducted } \\
\text { on the changes that have occurred in the performance } \\
\text { of the organization; }\end{array}$ \\
\hline $\begin{array}{l}\text { Relevance: the report should present the significant } \\
\text { economic, social, and environmental impact of the } \\
\text { organization and the significant influence of the } \\
\text { stakeholders' decisions; }\end{array}$ & $\begin{array}{l}\text { Accuracy: The reported information should be } \\
\text { sufficiently precise and detailed for stakeholders to } \\
\text { be able to properly assess the performance of } \\
\text { the organization; }\end{array}$ \\
\hline \multirow[b]{3}{*}{$\begin{array}{l}\text { Scope of application: The report should cover the } \\
\text { material aspects and their delimitation in a manner } \\
\text { that is sufficient to reflect the significant economic, } \\
\text { environmental, and social impacts, as well as to allow } \\
\text { stakeholders to assess the performance of the } \\
\text { organization during the reporting period. }\end{array}$} & $\begin{array}{l}\text { Opportunity: the information must be available in a } \\
\text { timely manner for the stakeholders' decisions; }\end{array}$ \\
\hline & $\begin{array}{l}\text { Intelligibility: the information must be presented in a } \\
\text { way that it is understood by all the stakeholders; }\end{array}$ \\
\hline & $\begin{array}{l}\text { Reliability: the information must be presented in the } \\
\text { report in a way that would allow for its examination, } \\
\text { in order to determine its quality and importance; } \\
\text { Clarity: the reporting organization shall make } \\
\text { information available in a manner that is } \\
\text { understandable and accessible to stakeholders using } \\
\text { that information. } \\
\text { Timelines: the reporting organization shall report on } \\
\text { a regular schedule so that information is available in } \\
\text { time for stakeholders to make informed decisions. }\end{array}$ \\
\hline
\end{tabular}

Source: Adapted from GRI 101: Foundation 2016, in "Consolidated Set of GRI Sustainability Reporting Standards", 2018, p. 13-16 [70].

GRI, through the versions it has prepared, is the most widely used model for CSR voluntary reporting worldwide. According to Figure 13, prepared based on the study conducted by KMPG in 45 countries, about $60 \%$ of the companies, on average, are using this model. The highest percentage of companies using GRI, namely 74\%, was recorded in America in 2013. There is, however, a decrease in the use of GRI in 2013, compared to 2015, for Europe, America, the Middle East, and Africa. Asia has recorded a $4 \%$ increase due to the increased use of GRI in countries like China, Indonesia, and India [71].

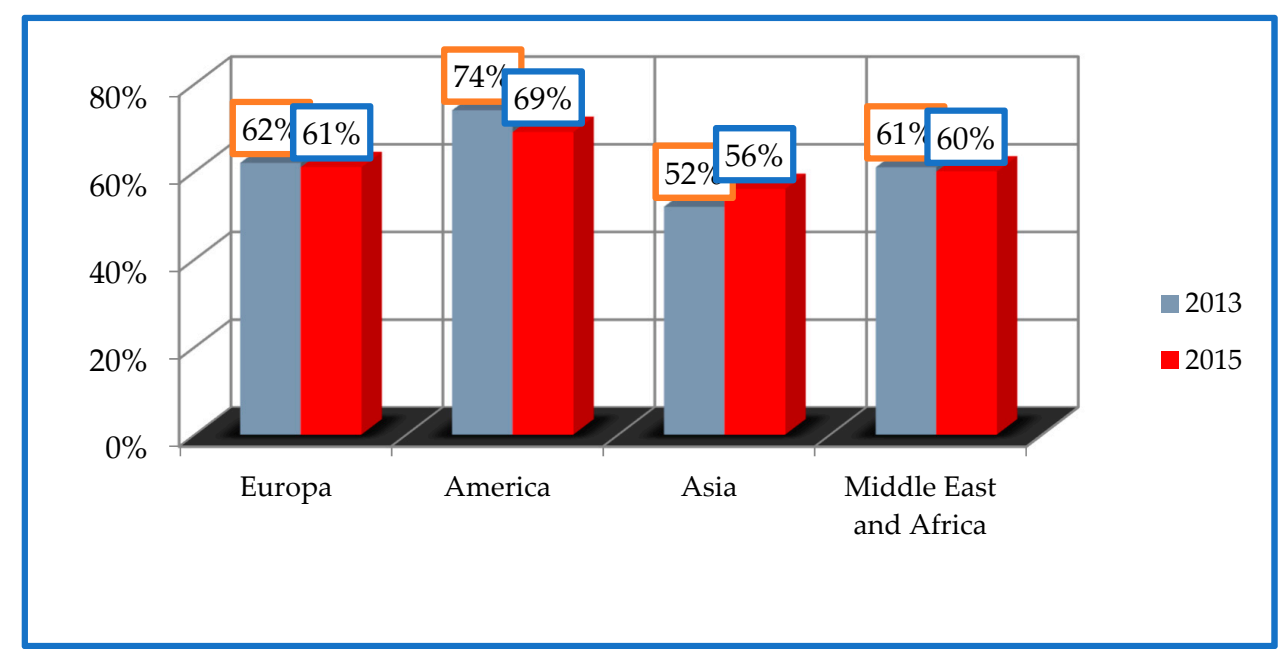

Figure 13. Usage degree of the GRI standard; Source: Adapted from KPMG "Survey of Corporate Responsibility Reporting” 2015; Sample: 3267 N100 companies reporting CSR [68]. 
The sustainability report model developed by GRI is deemed the most complex model of its kind and many of the companies that have applied it have also experienced with integrated reporting. Moreover, as evidenced by the literature, some authors consider the GRI model as a first step towards integrated reporting and even the G4 standard mentions the relationship existing between these two types of reporting and their differences.

In addition to what we mentioned above, we specify that Directive no. 95/2014 amending Directive 2013/34/EU regarding the presentation of non-financial information and information on diversity by certain enterprises and large groups, obliged the Romanian entities to publish a sustainability report.

The first integrated report was prepared in 2002 by a Danish company, Novozymes, and the large-scale adoption of IR by the listed companies occurred in 2009, in South Africa, by means of the King III Report. The task of developing a conceptual framework regarding IR lies with the International Integrated Reporting Council (IIRC), established in 2009 which prepared, in 2013, a conceptual framework for integrated reporting [72]. We would like to emphasize the fact that this type of reporting is aimed at corporations and multinational companies.

Table 4. Sustainability Reporting versus Integrated Reporting.

\begin{tabular}{cll}
\hline Items of Comparison & \multicolumn{1}{c}{ Sustainability Reporting } & Integrated Reporting \\
\hline Type of information & Provides mainly non-financial information; & $\begin{array}{l}\text { Is aimed at the value creation process from a } \\
\text { financial and non-financial perspective; }\end{array}$ \\
\hline Users of information & Is aimed at all the categories of stakeholders; & Is mainly aimed at investors; \\
\hline Time factor & Is focused on achieving long-term goals; & Short-, medium-, and long-term goals; \\
\hline Significant information & $\begin{array}{l}\text { May provide more information deemed } \\
\text { insignificant by certain users; }\end{array}$ & Focuses more on creating value; \\
\hline Scope of application & $\begin{array}{l}\text { The company's impact on the environment } \\
\text { and on society; }\end{array}$ & $\begin{array}{l}\text { Emphasises the way in which strategy, } \\
\text { governance and performance of a company } \\
\text { have led to creating value over time; }\end{array}$ \\
\hline Evaluation & $\begin{array}{l}\text { May be affected by difficult access to } \\
\text { non-financial information, as well as } \\
\text { its quantification; }\end{array}$ & The same applies to integrated reporting; \\
\hline \multicolumn{1}{c}{ Source: Adapted from [73]. }
\end{tabular}

Table 4 illustrates some of the differences that exist between sustainability reporting and integrated reporting. Integrated reporting is therefore seen as a contribution to decisions on how to allocate resources, especially limited or non-renewable ones, to create value in the short, medium, and long term, which leads us to think of sustainable development. Meanwhile, sustainability reporting contributes to determining the objectives and quantifying the performance of an entity in view of achieving long-term profitability, involving its social and environmental responsibility [74-76]. We believe that sustainability reporting, as it illustrates exclusively a long-term vision, is perceived as a limitation by many small and medium-sized enterprises. On the other hand, SR has the advantage of involving all stakeholder categories, compared to IR, which is mainly aimed at investors, a fact that may displease the other stakeholders and therefore have a negative impact on company image. Both types of reports use non-financial information that may be harder to quantify and understand by all the stakeholders. Therefore, we believe that there needs to be an effective dialogue between an entity and all the stakeholders, so that information of this kind be conveyed in a manner that would be understood by everyone and according to their expectations and that it should not focus on a single stakeholder category, because the entity will suffer, primarily in terms of image.

In this context, the budgeting activities and the information required are related with economic performance [77] and, consequently, there appears to be a necessity of implementing a set of measures regulating the efficiency of the budget also from fiscal point of view [78]. The research is properly linked with the catastrophe theory that covers the financial systems of the entities [79], in correlation with the dependence on the information technology (IT) [80]. 
In order to test the results of the questionnaire regarding the opportunity of voluntary disclosure and the options relation regarding the sustainable development of disclosure acceptance and the managers' perception in this respect, we propose to elaborate with the help of the statistical program GRETL a statistical model based on the least squares method, taking into consideration the following hypotheses:

1. Managers' acceptance of sustainable disclosure is directly proportional to the acceptance of the phenomenon and the methods of planning for the implementation of financial reports with voluntary disclosure.

2. The impediments to the application of voluntary disclosure are directly proportional to the acceptance of the phenomenon and to the economic sectors involved in the voluntary disclosure.

3. The main reasons for voluntary disclosure consist more of the foresight aspects of the development strategy and the provision of an attractive image of the company than in the field of sustainable development.

The proposed model is cumulative, it is based on the observations from the questionnaire survey (the options expressed by the respondents to the questionnaire), its econometric form being expressed by the equation

$$
\operatorname{Var}=\sum_{i=1}^{n} \alpha_{i} * R_{i}+\epsilon
$$

where

Var - the dependent variable of the model

$R_{i}$-regressors

$a_{i}$-regression coefficients

$\epsilon$-residual constant

The proposed model implies the definition of the 'Option' dependent variable-the management entities opening towards the process of voluntary disclosure and repressors.

1. Acceptance of the process;

2. Availability of future application of the disclosure procedure;

3. Planning the implementation of voluntary disclosure;

4. Important sections of voluntary disclosure;

5. Reasons for voluntary disclosure including by evaluating the effects of the phenomenon after implementation.

The model equation, based on the statistically disseminated results of the questionnaire, is defined as

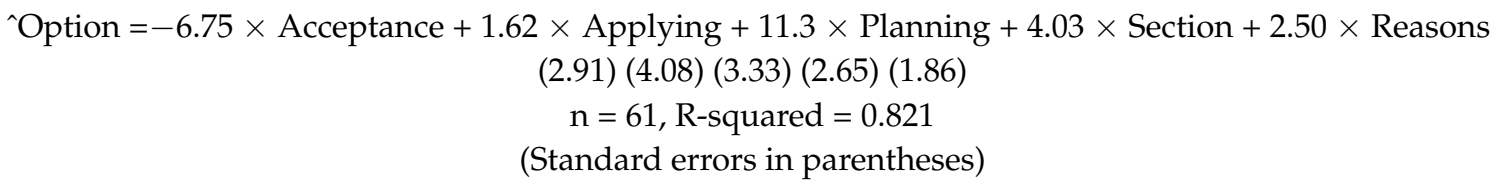

The proposed statistical model is representative for the studied phenomenon in proportion of $82.1 \%$ and has a high degree of statistical significance, as it can be seen from the tests below (Table 5): 
Table 5. Model 1: OLS, using observations 1-61 (Dependent variable: Option).

\begin{tabular}{cccccc}
\hline & Coefficient & Std. Error & t-ratio & $p$-value & \\
\hline Acceptance & -6.74883 & 2.91289 & -2.317 & 0.0242 & $* *$ \\
Applying & 1.62054 & 4.08298 & 0.3969 & 0.6929 & \\
Planning & 11.2992 & 3.33103 & 3.392 & 0.0013 & $* * *$ \\
Section & 4.02560 & 2.64714 & 1.521 & 0.1340 & \\
Reasons & 2.50035 & 1.85839 & 1.345 & 0.1839 & \\
\hline
\end{tabular}

$* *, * * *$ high level of statistical significance.

\begin{tabular}{cccc}
\hline Mean dependent variable & 31.00000 & S.D. dependent var. & 17.75293 \\
Sum squared reside & 13902.40 & S.E. of regression & 15.75618 \\
Uncentered R-squared & 0.820686 & Centred R-squared & 0.264812 \\
F $(5,56)$ & 51.26024 & $p$-value (F) & $1.13 \times 10^{-19}$ \\
Log-likelihood & -252.1380 & Akaike criterion & 514.2760 \\
Schwarz criterion & 524.8304 & Hannan-Quinn & 518.4124 \\
\hline
\end{tabular}

The statistical tests show the homogeneity of the model regarding the manager's option for voluntary reporting, with bringing up that this aspect was also confirmed by the interpretation of the questionnaire results. Statistical tests show that in the null hypothesis, the phenomenon of heteroscedasticity is not present, the error is normally distributed and the collinearity test reveals that there is a direct correlation of data and the absence of non-collinearity.

Breusch-Pagan test for heteroscedasticity -

Null hypothesis: heteroscedasticity not present

Test statistic: $\mathrm{LM}=3.09497$

with $\mathrm{p}$-value $=\mathrm{P}($ Chi-square $(5)>3.09497)=0.685346$

Test for normality of residual -

Null hypothesis: error is normally distributed

Test statistic: Chi-square $(2)=0.68003$

with $p$-value $=0.71176$

Non-linearity test (squares) -

Null hypothesis: relationships linear

Test statistic: $\mathrm{LM}=29.0323$

with $p$-value $=\mathrm{P}($ Chi-square $(5)>29.0323)=2.28519 \times 10^{-0.05}$

The Figure 14 shows the distribution of the dependent variable in the normal quantities to the right of the prognosis, observing the homogeneity of the model.

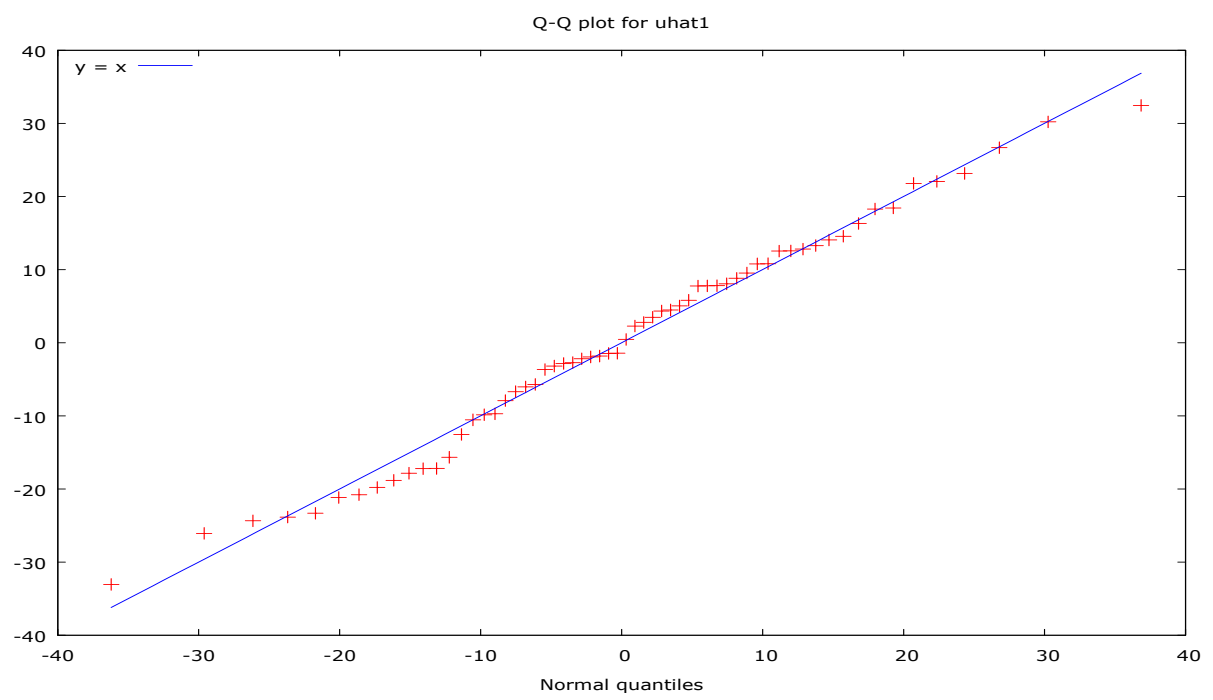

Figure 14. Q-Q plot distribution of the dependent variable. 
Through the phenomenon of foresight of the phenomenon evolution trend on confidence intervals of $95 \%$, it is found that in relation to the regressors of the model there is a positive evolution of the voluntary disclosure acceptance, which is shown by the Figure 15 .

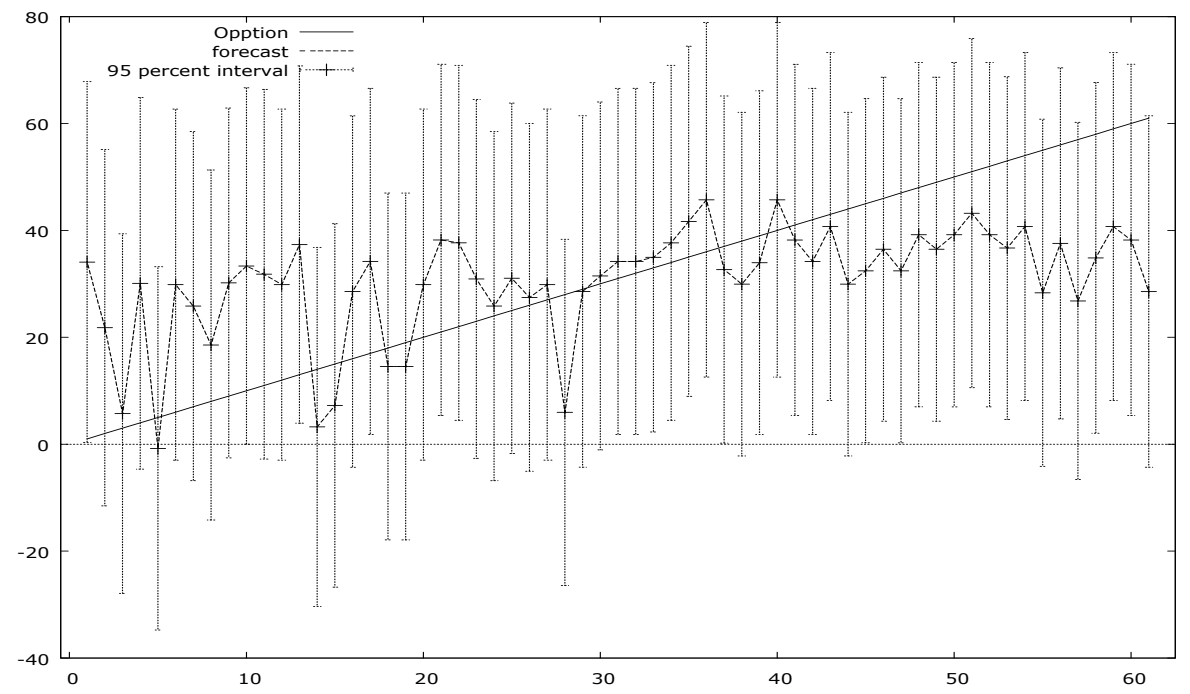

Figure 15. Normal distribution of the phenomenon to the right of the predicted prognosis on the confidence interval of $95 \%$.

In order to demonstrate the validity of the model, the normality test of residual values was performed, a statistical test which, for the value Hi square $=0.68$ generated a distribution interval $\mathrm{N}(0.32-15.75)$.

In the distribution interval we find that the values are homogeneous, respecting the Gaussian distribution curve, according to the Figure 16.

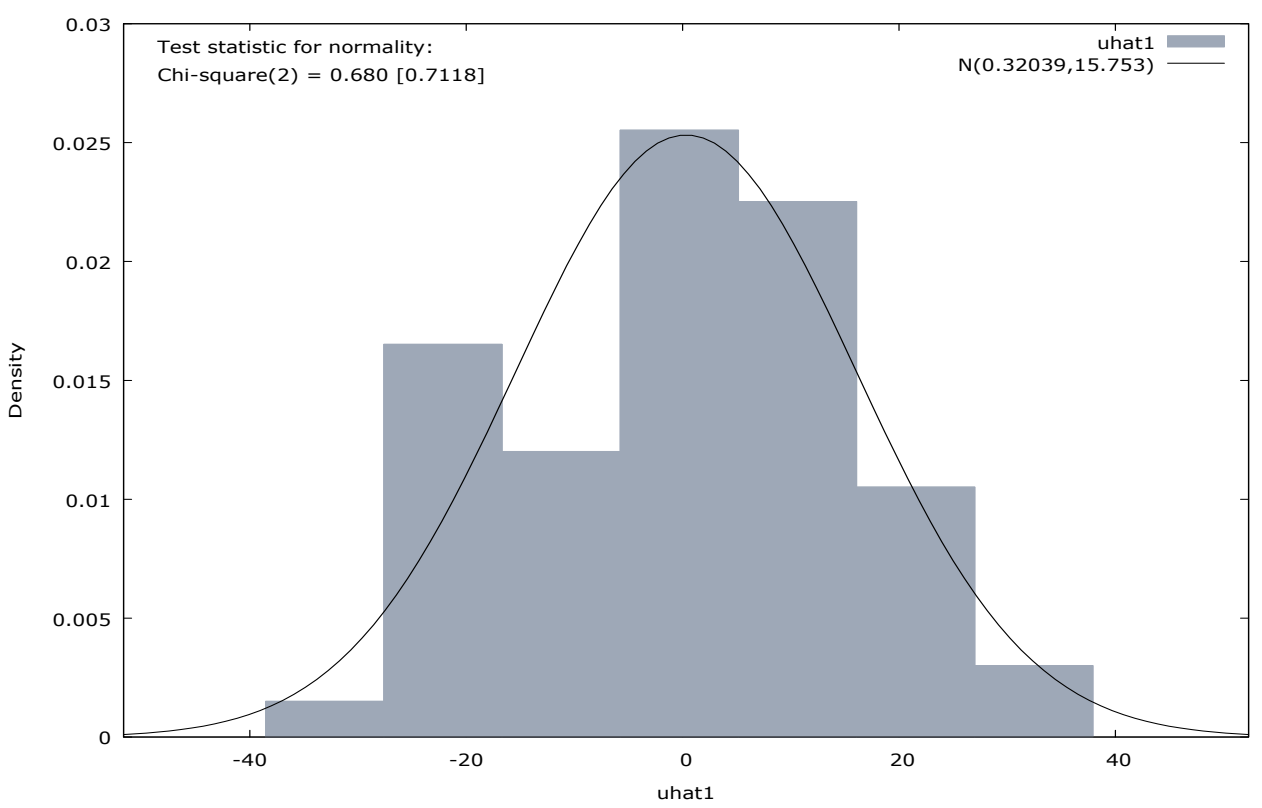

Figure 16. Test of normal distribution of the residual variable.

\section{Results and Discussions}

CSR is generally voluntary. There are: social reports, environmental balance sheets, eco balances, and sustainability reports. Companies basically turn to a standardized model, but there are also companies that adopt their own model that meets certain standards. 
Large companies are the main entities that prepare this voluntary reporting for social and environmental issues. The difference between large multinational companies and micro-enterprises reside in the way in which they make their mark by their reporting on social responsibility activities. The contribution of a micro-enterprise in terms of social responsibility can generally be more focused on the local community and has no need for a marketing budget, when it comes to large corporations [81]. We believe that this is one of the reasons why many micro-enterprises, while proving their commitment to social responsibility through various programmers or activities, do not report them. There is also the reason of the cost of voluntary reporting, as the cost-benefit criterion also applies here, just as it does for the financial reporting.

In conclusion, small and medium-sized enterprises do not have the additional financial resources that are necessary for the next step, i.e., social responsibility voluntary reporting as for the large corporations, due to the fact that they have their own social responsibility department.

The effective assessment of the level of integration of CSR initiatives in decision-making processes cannot overlook a simultaneous analysis of all dimensions explaining responsible social behaviors. Basically, our goal is to 'define' the size of CSR-oriented enterprises, namely those who may be interested in developing an integrated management system that includes social and environmental considerations/variables in all categories of stakeholders (both internal and external) the entity it interacts with.

In this regard, we chose to identify a group of 61 economic entities operating in the industrial sector, the marketing of consumer goods and services (this implied a gradual assessment of their size, their business, and stakeholder relations), so that we could investigate and evaluate the integration possibilities that fall within the internal or external dimension of CSR.

In 2014, based on a regulation designed by the Romanian MFP (OMFP 1802/2014 in accordance with Directive 34 EEC/2014), the enterprises needed to be classified according to their size into three important parameters: turnover, number of personnel, number of employees, and total assets. One can notice the fact that the entire group of companies under review is classified, based on these latest legislative changes at the EU level, into micro-enterprises and small enterprises. Given their field of activity and the magnitude of these relevant financial indicators used in the classification of entities in Romania, we believe that social and environmental empowerment of these entities whose management culture is low compared to EU countries is of uttermost importance.

In spite of the fact that there is a strong interest in the management of these companies that are making extra efforts regarding the costs of voluntary (additional) reporting, we strongly believe that, as far as the Romanian entities are concerned, a certain orientation towards external stakeholders such as protecting the clients' interests (initiatives that guarantee transparent communication in regards to the quality of the products or services offered) which are concurrent with the attention given to the suppliers' requirements (who can be made more aware of the social and environmental issues that may influence the business report) resulting from the negotiated contracts are to be noticed.

The final results lead to a more in-depth research of the CSR phenomenon by explaining how practices and instruments of social responsibility are correlated with each other, to what extent they are known by micro-enterprises and small businesses in Romania, as well as to what extent they would be willing (if they are not aware of the importance of CSR orientation) to make further efforts to adopt or refine these policies and tools.

Our study, in which we identified the field of activity and the size of the entities, highlights the connections between the different forms of social responsibility (in terms of size, field of activity, and geographical position). The orientation of these companies towards CSR cannot be conditioned only by the basic features of these entities and by the cultural, social, and geographical context in which these entities operate. They cannot solely rely on the typological peculiarities and the intensity of the effort on social and environmental reporting. The results of our study revealed a $67 \%$ increased concern of large, medium, small, and micro-entities in improving their communication process and information transparency through the introduction of supplementary reporting that refers to the information in the social and environmental domains (we emphasize the fact that the group of companies that were analyzed 
is made of entities that do not belong to the industrial sector). Based on the size of these entities, we have found that an integrated approach to different CSR interventions would be much easier. It is worth mentioning the fact that, in regards to small entities (small entities and micro entities) having limited economic resources allocated to CSR investments, there is a willingness to implement at least one CSR tool. It is important to highlight the position of these Romanian enterprises as they can determine emulation or imitation phenomena between companies that exist at least on a local level within distinct geographic areas. Another aspect would refer to the fact that the same stakeholders have new information requirements that these companies have to meet, by giving them a wider range of actions, management tools, and certification.

Therefore, our study has noticed not only the need for quantitative measurement of new forms that are brought about in time, but also the need to monitor new analytical approaches, which, in our case, refer not only to mandatory, but also to voluntary practice that is not legally imposed. The study highlights the intention of these entities to implement social and environmental responsibility policies and instruments due to the fact that they are aware that it can be a real means of control and intervention on the company's involvement in the community and the environment by generating benefits for all participants in economic life and social life. The aim of focusing on enhancing mandatory reporting through voluntary reporting raised awareness of social, environmental, and sustainability issues with a special attention to promoting and involving the CSR cultures in the present economic context. Starting from the analysis of the responses and the availability of the entities in order to optimize their reporting by introducing additional information (environmental and social), it was possible to highlight the concerns and the consequences of the actions related to the existing social responsibility of the small enterprises. As far as they are concerned, it is very difficult to identify officially undertaken actions attributed to CSR due to the fact that they are rather associated with ethical cultures of a company.

The research is especially useful for the strategic management process that is used by managers in the stages of the companies' economic development, for the national and European organizations that are interested in implementing sustainable development processes, potential investors, beneficiaries of the voluntary reporting procedures, and — last but not least—-the academic environment by providing consistent information on the theoretical approach to the CSR versus the sustainability concept and statistical models in order to analyze the correlation between these processes (see Table 6).

Table 6. CSR and Additional Voluntary Reporting by Company Size

\begin{tabular}{|c|c|c|c|c|}
\hline Name of the Indicators & General 100\% & Large Companies $7 \%$ & IMM 54\% & Micro-Enterprises 39\% \\
\hline \multirow{2}{*}{$\begin{array}{l}\text { I.1 Opinion on the need } \\
\text { for additional } \\
\text { financial reporting }\end{array}$} & $+52.46 \%$ & $+75 \%$ & $+36.36 \%$ & $+70.83 \%$ \\
\hline & $-47.54 \%$ & $-25 \%$ & $-63.64 \%$ & $-29.17 \%$ \\
\hline
\end{tabular}


Table 6. Cont.

\begin{tabular}{|c|c|c|c|c|}
\hline Name of the Indicators & General $100 \%$ & Large Companies $7 \%$ & IMM 54\% & Micro-Enterprises 39\% \\
\hline \multirow[t]{2}{*}{$\begin{array}{l}\text { I.2 Managers' } \\
\text { involvement }\end{array}$} & $\begin{array}{l}\text { The managers' } \\
\text { involvement in } \\
\text { voluntary reporting is } \\
\text { more skeptical than the } \\
\text { general opinion on the } \\
\text { need for additional } \\
\text { information, the trend } \\
\text { being slightly reversed } \\
\text { and the respondents. }\end{array}$ & $\begin{array}{l}\text { As for large } \\
\text { enterprises, some } \\
\text { respondents refrained } \\
\text { themselves from } \\
\text { providing a clear } \\
\text { answer as to how rap } \\
\text { managers are } \\
\text { supplemented by } \\
\text { voluntary } \\
\text { reporting tools. }\end{array}$ & $\begin{array}{l}\text { In the case of IMMs, } \\
\text { the respondents' option } \\
\text { of supplementing the } \\
\text { management report } \\
\text { respects the view of the } \\
\text { need for voluntary } \\
\text { reporting entirely (with } \\
\text { the same degree of } \\
\text { skepticism). In this case, } \\
\text { it is proven by the study } \\
\text { that small and } \\
\text { medium-sized } \\
\text { enterprises are most } \\
\text { reluctant to implement } \\
\text { voluntary reporting, } \\
\text { and the phenomenon of } \\
\text { CSR is seen as having } \\
\text { minimal impact on the } \\
\text { company's further } \\
\text { development, } \\
\text { the minimum value } \\
\text { being reached in relation } \\
\text { to other types of entities } \\
\text { (large and } \\
\text { microenterprises). }\end{array}$ & $\begin{array}{l}\text { In the case of } \\
\text { micro-enterprises, there is } \\
\text { the same tendency of } \\
\text { skepticism as regards the } \\
\text { supplementation of } \\
\text { management reporting, } \\
\text { skepticism generally } \\
\text { attributable to the lack of } \\
\text { delegation and the } \\
\text { accumulation of functions } \\
\text { that are incidental to the low } \\
\text { HR phenomenon. }\end{array}$ \\
\hline & $\begin{array}{l}-50.82 \% \\
* 4.92 \% \text { are } \\
\text { * } \\
\text { abstained }\end{array}$ & $\begin{array}{c}-25 \% \\
* 25 \% \text { are } \\
\text { abstained }\end{array}$ & $-63.64 \%$ & $\begin{array}{c}-37.5 \% * 8.33 \% \\
\text { are abstained }\end{array}$ \\
\hline $\begin{array}{l}\text { I.5 Future application of } \\
\text { voluntary disclosure }\end{array}$ & $\frac{\begin{array}{c}+54.10 \% \\
*+3.28 \% \\
\text { conditioned }\end{array}}{{ }^{*} 42.62 \%}$ & $-25 \%$ & $\frac{\begin{array}{c}+66.67 \% * \\
+3.03 \% \\
\text { conditioned }\end{array}}{* 30.30 \%}$ & $\begin{array}{l}{ }^{*} 66.7 \% \\
\text { abstentions }\end{array}$ \\
\hline
\end{tabular}


Table 6. Cont.

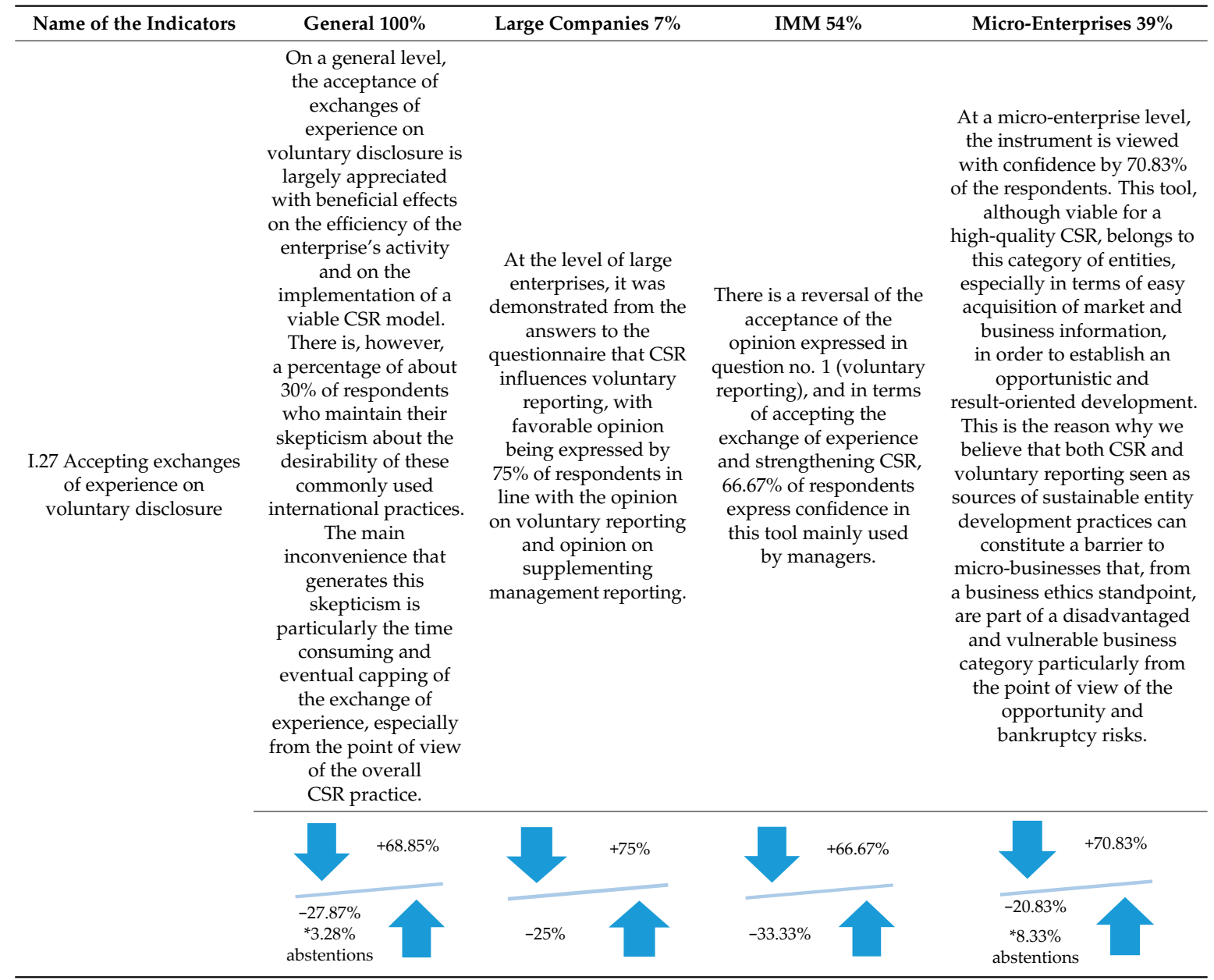

Source: Own calculations.

We compared the need for additional voluntary reporting in relation to the managers' willingness to complete the management report by voluntary reporting. An extra caution was noticed in the form of management reporting responses, which indicates that the responses were given by individuals with managerial duties capable of objectively assessing the need for financial and yet subjective information regarding the assumption of individual tasks by completing the management report, with more skepticism in this matter than with the option of voluntary reporting.

If we are referring to the behavior oriented towards CSR and financial performance, we can say that there is a positive correlation between the two elements which ultimately leads to obvious benefits in terms of productivity, the improvement of the ratio regarding customers, investors, suppliers, and creditors, as well as the reduction of financial risk. Thus, it can be noticed that even if there are limits on the size of these companies, since they are willing to adopt an environmentally and socially responsible behavior, they do not have the value of higher performance indicators compared to reluctant companies that are reluctant to CSR. We can even say that the enterprises oriented towards satisfying the interests of the external stakeholders (especially customers and consumers) exhibit a lower sales trend (emphasized by the turnover) than other enterprises. The explanation might be that they have already introduced certain CSR-related management systems to benefit from competitive advantages to conquer lost market niches or to reposition themselves towards a segment of customers more sensitive to social and environmental issues. The very varied nature and typology of factors that exert a significant influence on an enterprise's economic performance makes it quite difficult to identify a direct causal relationship between CSR investments and their performance. The analysis of corporate 
CSR-oriented behavior and the achieved economic performance over a period of at least five years could allow for a future change on terms of the managerial strategies for the Romanian enterprises.

In Romania, the concept of corporate social responsibility is a relatively new field, which has developed accordingly since the country's accession to the EU and is present mainly in multinational companies. The concept has been implemented in our country by the multinational companies that, through their activities, transfer their social responsibility practices to the market. For national companies, social responsibility was initially seen more as a fashion trend or as a marketing strategy, yet it was also considered from the perspective of the desire to align it with certain international and European business standards. Later on, due to market competitiveness, national companies have become aware of the importance of the role of CSR for medium- and long-term success [82].

In our country, the legislation does not provide the mandatory disclosure of social or environmental aspects in financial statements or as separate reports, either for listed or unlisted companies. This information is usually made public by large corporations. In fact, entities that have adopted the IAS/IFRS standards in our country are required to provide detailed environmental or employee information in the explanatory notes to the annual financial statements. However, our country will have to align with the 2014/95/EU Directive [83], which introduces mandatory social reporting. As a result of the amendments to the European Directive 2013/34/EU [84], businesses based in the Member States have a duty to prepare a non-financial statement. This includes large corporations that, as of the balance sheet date, exceed the average 500 employees' criterion during the financial year, as well as parent companies of a group that, as of the date of the balance sheet based on consolidation, exceed that very same criterion. This provision applies to enterprises that meet the criteria set for the financial year starting on 1 January 2017 or during 2017 [85]. Starting with 2017, more than 6000 large European companies are expected to have, a legal obligation to ensure that non-financial information is reported.

In the US, all the companies that have more than 10 employees and use or emit certain toxic gases are forced by the US Environmental Protection Agency to report these emissions in their environmental reports. The SEC (Securities and Exchange Commission) demands the disclosure of information and environmental debt based on the Form 10-K [85].

In France, the New Economic Regulation (2002) provides for the mandatory reporting of listed companies on environmental impact. There is no specific regulation in Germany that requires mandatory environmental reporting. There is, however, a guide on environmental reporting that establishes the minimum amount of information to be included in the annual reports. In Sweden, companies whose operation includes emission certificates are required to report their environmental performance to the authorities. Moreover, since 1999, various groups of entities must include their environmental performance in their annual financial statements; the same applies to the Netherlands [68]. In the United Kingdom, in 2005, the Companies Act provided for the publication of environmental and social information, as well as of community interest information, and the law also applies to unlisted companies [86].

After 2000, the European Union has conducted a broad campaign to promote the concept of social responsibility among Member States and has developed several legal instruments to define a European framework for social responsibility. As such, the European Commission's Green Paper of 2001 [87] defines social responsibility as representing the concept by which companies integrate social and environmental objectives into their commercial operations and into the relationships with all stakeholders, on a voluntary basis.

Starting from the theories identified in specialized literature, namely: institutional theory, stakeholder theory, and legitimacy theory-which according to some authors [85] are interdependent, not competing but complementary-we have applied a critical study of their limits, concluding that the concept of CSR vs. sustainability can be better represented by a statistical model whose hypotheses are targeted that the acceptance of manager and the impediments to the application of voluntary disclosure are directly proportional to the acceptance of the phenomenon and the planning methods. It has also been demonstrated that the main reasons lie more in certain aspects of the development 
strategy and in ensuring an attractive image of the company. Moreover, it has been demonstrated that voluntary reporting can be seen as a simplified part of CSR provided the establishment of clear objectives and the take-over by managers of voluntary implementation tools. This reporting can lead to a sustainable short-term and long-term development.

To sum up, CSR reporting is not just voluntary. In many countries around the world, various regulations, European and international standards or guidelines, have been adopted regarding applying the social responsibility which has resulted in the duty of the entities to report financial and non-financial information related to the social and environmental aspects.

\section{Conclusions}

In this paper, we developed a survey based on a questionnaire regarding the acceptance of voluntary reporting and its relationship with sustainable development as a strategic direction of interest for the entities management.

The questionnaire has allowed collecting some valuable information that has been centralized according to its building sections in impact assessment studies of voluntary disclosure, useful studies in the opinion of the authors, given the current efforts made by international forums in the accounting field to regulate this issue.

Our study has highlighted the fact that the profile of CSR-oriented entities is obviously influenced by the field of activity and the size of the entity. However, there are also differences resulting from strategies that are geared towards the social responsibility development. The grouping of the analyzed enterprises was based on their specialization such as traditional and small-scale business areas, micro-enterprises. Nevertheless, as the questions show, they are willing to consolidate their position on the market (even if most of them have maintained their turnover) through additional/voluntary reporting that requires additional costs. This means that they have an opening as far as the components of social and environmental responsibility are concerned. Thus, we can say that employing these small enterprises in relation to CSR means that they have ethical and economic motivations rather than getting immediately and at any cost a positive response from the market they operate in. The availability (that was showed by the analyzed responses), as a desire to consolidate the image of the company and increase the reputation among the clients, is basically the main reason for adopting a responsible social behavior, a superior behavior to the ethical reasons, as it can effectively contribute to solving social and environmental problems.

At the end of our analysis, one can find a full picture of the Romanian enterprises oriented towards additional reporting and implicitly towards CSR that are willing to explicitly incorporate social responsibility into their own economic development plan and contribute to building their own social and environmental economic footprint, i.e., a distinct organizational culture. Despite ensuring transparency of the information, CSR does not adopt in a common form those various instruments for managing the social and environmental responsibility (the ethical code, the environmental report, the social balance, or certain proofs and certificates required by the legislation in force). Even if in our case the number of entities using these instruments is low, it does not mean that they should be excluded a priori from the group of those who expressed their willingness to report additional information through the environmental or social balance as they might only be concerned to obtain these certificates or proofs that require the necessity to comply with certain quality standards. However, this kind of enterprise has a different view than those who are oriented or are willing to move towards CSR because their strategies do not focus on the structural features of those that are CSR oriented.

It is a fact that micro-enterprises and small enterprises as part of the target group are concerned with adopting CSR management tools, especially those that are closer to their objectives, or with improving the stakeholder relationship (through better communication).

The research is especially useful for the strategic management process that is used by managers in the stages of a company's economic development, for the national and European organizations that are interested in implementing sustainable development processes, the potential investors, the beneficiaries 
of the voluntary reporting procedures and, last but not least, the academic environment by providing consistent information on the theoretical approach to the CSR versus the sustainability concept and statistical models in order to analyze the correlation between these processes.

Sustainable development represents a subject of interest in both European and national policy opportunities through the implementation of sound sustainable economic development trends in line with the European values in terms of security, environmental protection, and social inclusion. As the study shows, there is a concern among specialists regarding the sustainable development on the entity level regarding the CSR concept. This concept implies the fact that the entity is accountable in two compliance respects through mandatory and voluntary reporting. Numerous studies conducted by specialized organizations (KPMG, Ernest \& Young, Deloitte \& Touché LLP) have signaled the need for implementing a CSR model based on the integration of the two components following the verification and financial control procedures. In this context, we identified based on a questionnaire designed between 2015-2017 a model of conditional acceptance of CSR for managers. This model is based on the development of a statistical model of CSR correlation and sustainable development. The model hypotheses have been statistically tested to obtain high significance thresholds and demonstrating the validity of the model. The proposed model presents some limitations regarding the inclusion of all significant variables to be tested as regression variables: acceptability, applicability, planning, and motivation.

It ensures the future development of the model by creating new relevant indicators and their inclusion in the statistical testing procedure and, at the same time, it creates an opportunity for the authors to subsequently develop a causal model linking the proposed model to CSR compliance and development sustainable compliance.

The research materialized with the development of a statistical model for assessing the acceptability of disclosure and the positioning of sustainable development as an area of interest for managers.

Since the data gathered is related to a group of 61 entities of various sizes, we believe that this is one of the limits of the present research. In conclusion, we believe it would be interesting to extend the study to a larger group, thus finding out whether the data are retained or not in a larger volume.

The difficulties encountered in our research have mainly referred to the fact that the analyzed Romanian companies, not being quoted on the stock exchange, have imposed a limitation only regarding information on the reported economic and financial indicators, as well as to the data obtained through questionnaires. Although a guideline of these companies is noted for CSR, there is still no culture, a clear conviction that the implementation of a strategy aimed at social and environmental responsibility policies could contribute over time in a significant way to increasing sustainability performance, but especially to enhancing the quality of community life these companies operate in.

Author Contributions: M.S., V.G., E.H. and S.S. conceptualized the study and choose the theoretical framework, collected the data, analyzed them, and wrote the paper together, revising the manuscript several times.

Funding: This research received no external funding.

Acknowledgments: The authors want to thank particularly the reviewers for the suggestions and recommendations received and who contributed in a meaningful manner to improving the quality of the work.

Conflicts of Interest: The authors declare no conflict of interest.

\section{References}

1. Yongvanich, K.; Guthrie, J. An Extended Performance Reporting Framework for Social and Environmental Accounting. Bus. Strategy Environ. 2006, 15, 309-321. [CrossRef]

2. Nedelea, A.; Grosu, V.; Elmazi, L. Ecotourism in Sustainability of a Developing Country. Bull. UASVM Hortic. 2008, 65, 455 .

3. Socol, C.; Marinas, M.; Socol, A.; Armeanu, D. Fiscal Adjustment Programs versus Socially Sustainable Competitiveness in EU Countries. Sustainability 2018, 10, 3390. [CrossRef] 
4. Miglè, Š.P. CSR Reasons, Practices and Impact to Corporate Reputation. Procedia Soc. Behav. Sci. 2015, 213, 503-508.

5. Belal, A.R.; Cooper, S.M.; Khan, N.A. Corporate environmental responsibility and accountability: What chance in vulnerable Bangladesh? Crit. Perspect. Account. 2015, 33, 44-58. [CrossRef]

6. Lauwo, S.; Otusanya, O.J. Corporate accountability and human rights disclosures a case study of Barrick GoldMine in Tanzania. Account. Forum 2014, 38, 91-108. [CrossRef]

7. Ionescu, R.V.; Zlati, L.M.; Antohi, V.; Stanciu, S. Reduced Inequalities as Factor of Sustainable Development: The Analysis Under Econometric Models. Sustainability 2018, 10, 3523. [CrossRef]

8. Lauwo, S.G.; Otusanya, O.J.; Bakre, O. Corporate social responsibility reporting in the mining sector of Tanzania: (Lack of) government regulatory controls and NGO activism. Account. Audit. Account. J. 2016, 29, 1038-1074. [CrossRef]

9. Cochran, P.L. The evolution of corporate social responsibility. Bus. Horiz. 2007, 50, 449-454. [CrossRef]

10. Votaw, D. Genius becomes rare: A comment on the doctrine of social responsibility. Calif. Manag. Rev. 1972, 15, 25-31. [CrossRef]

11. Carroll, A.B.A. Three-Dimensional Conceptual Model of Corporate Performance. Acad. Manag. Rev. 1979, 4, 497-505.

12. Windsor, D. Corporate social responsability. Three key Approches. J. Manag. Stud. 2006, 43, 93-114. [CrossRef]

13. Ellen, P.S.; Webb, D.J.; Mohr, L.A. Building corporate associations: Consumer attributions for corporate socially responsible program. J. Acad. Mark. Sci. 2006, 34, 147-157. [CrossRef]

14. Margolis, J.D.; Walsh, J. Misery loves companies: Rethinking social initiatives by business. Adm. Sci. Q. 2003, 48, 268-305. [CrossRef]

15. Dang, C.; Li, Z.F. Measuring Firm Size in Empirical Corporate Finance. J. Bank. Finance 2018, 86, $159-176$. [CrossRef]

16. Coles, J.L.; Li, Z.F.; Wang, A.Y. Industry Tournament Incentives. Rev. Financ. Stud. 2018, 31, 1418-1459. [CrossRef]

17. Hong, B.; Li, Z.F.; Minor, D. Corporate Governance and Executive Compensation for Corporate Social Responsibility. J. Bus. Ethics 2016, 136, 199-213. [CrossRef]

18. Core, J.; Guay, W. The Use of Equity Grants to Manage Optimal Equity Incentive Levels. J. Account. Econ. 1999, 28, 151-184. [CrossRef]

19. Giroud, X.; Mueller, H.M. Corporate Governance, Product Market Competition, and Equity Prices. J. Finance 2011, 66, 563-600. [CrossRef]

20. Li, Z.F. Mutual Monitoring and Corporate Governance. J. Bank. Finance 2014, 45, 255-269.

21. Beck, C.; Frost, G.; Jones, S. CSR Disclosure and Financial Performance Revisited: A Cross-Country Analysis. Aust. J. Manag. 2018, 43, 517-537. [CrossRef]

22. Chen, C.S.; Yu, C.C.; Hu, J.S. Constructing Performance Measurement Indicators to Suggested Corporate Environmental Responsibility Framework. Technol. Forecast. Soc. Chang. 2018, 135, 33-43. [CrossRef]

23. Fordham, A.E.; Robinson, G.M.; Cleary, J.; Blackwell, B.D.; van Leeuwen, J. Use of a Multiple Capital Framework to Identify Improvements in the CSR Strategies of Australian Resource Companies. J. Clean. Prod. 2018, 200, 704-730. [CrossRef]

24. Høvring, C.M.; Andersen, S.E.; Nielsen, A.E. Discursive Tensions in CSR Multi-Stakeholder Dialogue: A Foucauldian Perspective. J. Bus. Ethics 2018, 152, 627-645. [CrossRef]

25. Lee, H.H.; Lee, M.; Ma, Y.J. Consumer Responses to Company Disclosure of Socially Responsible Efforts. Fash. Text. 2018, 5, 27. [CrossRef]

26. Obara, L.J.; Peattie, K. Bridging the Great Divide? Making Sense of the Human Rights-CSR Relationship in UK Multinational Companies. J. World Bus. 2018, 53, 781-793. [CrossRef]

27. Reimsbach, D.; Wang, Z.; Braam, G. Political Embeddedness and the Diffusion of Corporate Social Responsibility Practices in China: A Trade-off between Financial and CSR Performance? J. Clean. Prod. 2018, 198, 1185-1197.

28. Shi, H.; Zhang, X.; Zhou, J. Cross-Listing and CSR Performance: Evidence from AH Shares. Front. Bus. Res. China 2018, 12, 11. [CrossRef]

29. Tsalis, T.A.; Stylianou, M.S.; Nikolaou, I.E. Evaluating the Quality of Corporate Social Responsibility Reports: The Case of Occupational Health and Safety Disclosures. Saf. Sci. 2018, 109, 313-323. [CrossRef] 
30. Calveras, A.; Ganuza, J.J. Corporate Social Responsibility and Product Quality. J. Econ. Manag. Strategy 2018, 27, 804-829. [CrossRef]

31. Hoi, C.K.; Wu, Q.; Zhang, H. Community Social Capital and Corporate Social Responsibility. J. Bus. Ethics 2018, 152, 647-665. [CrossRef]

32. Buchanan, B.; Cao, C.X.; Chen, C. Corporate Social Responsibility, Firm Value, and Influential Institutional Ownership. J. Corp. Finance 2018, 52, 73-95. [CrossRef]

33. Teoh, H.S.; Welch, I.; Wazzan, C.P. The effect of socially activist investment policies on the financial markets: Evidence from the South African boycott. J. Bus. 1999, 72, 35-89. [CrossRef]

34. Kang, S.; Han, S.; Bang, J. The Fit between Employees' Perception and the Organization's Behavior in Terms of Corporate Social Responsibility. Sustainability 2018, 10, 1650. [CrossRef]

35. Turker, D. How corporate social responsibility influences organizational commitment. J. Bus. Ethics 2009, 89, 189-202. [CrossRef]

36. Green Paper: Promotind a European Framework for Corporate Social Responsibility; Commission of the European Communities: Brussels, Belgium, 18 July 2001.

37. Botezatu, M.; Jean, A. Implications of the environmental factors on the economic efficiency of capital investments. A Romanian perspective in terms OFA sustainable economy. J. Environ. Prot. Ecol. 2012, 13, 382-391.

38. Hart, S. Capitalism at the Crossroads: Aligning Commerce, Earth, and Humanity, 2nd ed.; FT Press: Upper Saddle River, NJ, USA, 2007.

39. Margolis, J.D.; Elfenbein, H.A.; Walsh, J.P. Does it Pay to be Good? A Meta-Analysis and Redirection of Research on the Relationship between Corporate Social and Financial Performance. J. Chem. Inf. Model. 1989, $53,160$.

40. Russo, M.V.; Fouts, P.A. A resource-based perspective on corporate environmental performance and profitability. Acad. Manag. J. 1997, 40, 534-559.

41. Surroca, J.; Tribó, J.A.; Waddock, S. Corporate responsibility and financial performance: The role of intangible resources. Strateg. Manag. J. 2010, 31, 463-490. [CrossRef]

42. Walley, N.; Whitehead, B. It's not easy being green. Harv. Bus. Rev. 1994, 72, 46-52.

43. McWilliams, A.; Siegel, D. Corporate Social Responsibility and Financial Performance: Correlation or Misspecification? Strateg. Manag. J. 2000, 21, 603-609. [CrossRef]

44. Qian, W.; Junsheng, D.; Shenghua, S. A meta-analytic review of corporate social responsibility and corporate financial performance: The moderating effect of contextual factors. Bus. Soc. 2015, 55, 1-39.

45. Orlitzky, M.; Schmidt, F.L.; Rynes, S.L. Corporate Social and Financial Performance: A Meta-Analysis. Organ. Stud. 2003, 24, 403-441. [CrossRef]

46. Coenenberg, A.G.; Haller, A.; Schultze, W. Jahresabschluss und Jahresabschlussanalyse: Betriebswirtschaftliche, Handelsrechtliche, Steuerrechtliche und Internationale Grundlagen: HGB, IAS/IFRS, US-GAAP, DRS [Annual Financial Statements and Financial Statements Analysis: Economic, Commercial Law, Tax Law and International Foundations: HGB, IAS/IFRS, US-GAAP, DRS]; Schäffer-Poeschel: Stuttgart, Germany, 2016.

47. Ullmann, A.A. Data in Search of a Theory: A Critical Examination of the Relationships among Social Performance, Social Disclosure, and Economic Performance of U.S. Firms. Acad. Manag. Rev. 1985, 10, 540. [CrossRef]

48. Waddock, S.A.; Graves, S.B. The Corporate Social Performance-Financial Performance Link. Strateg. Manag. J. 1997, 18, 303-319. [CrossRef]

49. Peloza, J. The Challenge of Measuring Financial Impacts from Investments in Corporate Social Performance. J. Manag. 2009, 35, 1518-1541. [CrossRef]

50. Arya, B.; Zhang, G. Institutional Reforms and Investor Reactions to CSR Announcements: Evidence from an Emerging Economy. J. Manag. Stud. 2009, 46, 1089-1112. [CrossRef]

51. Barnett, M.L.; Salomon, R.M. Beyond dichotomy: The curvilinear relationship between social responsibility and financial performance. Strateg. Manag. J. 2006, 27, 1101-1122. [CrossRef]

52. Wright, P.; Ferris, S.P. Agency Conflict and Corporate Strategy: The Effect of Divestment on Corporate Value. Strateg. Manag. J. 1997, 18,77-83. [CrossRef]

53. Kocmanová, A.; Dočekalová, P.M.; Škapa, S.; Smolíková, L. Measuring Corporate Sustainability and Environmental, Social, and Corporate Governance Value Added. Sustainability 2016, 8, 945. [CrossRef]

54. Bostan, I.; Mateş, D.; Hlaciuc, E.; Grosu, V.; Iancu, E.; Socoliuc, M. Implications of the EVA model use in the firm resources' performant allocation plan. Int. J. Account. Inf. Manag. 2011, 19. [CrossRef] 
55. Lozano, R.; Carpenter, A.; Huisingh, D. A review of "theories of the firm" and their contributions to Corporate Sustainability. J. Clean. Prod. 2014, 106, 1-13. [CrossRef]

56. Porter, M.; Kramer, M. Strategy and society: The link between competitive advantage and corporate social responsibility. Harv. Bus. Rev. 2006, 84, 78-92. [PubMed]

57. Smith, C.N. Corporate social responsibility: Whether or how? Calif. Manag. Rev. 2003, 45, 52-76. [CrossRef]

58. Siltaoja, M.L. Value priorities as combining core factors between CSR and reputation-A qualitative study. J. Bus. Ethics 2006, 68, 91-111. [CrossRef]

59. Fombrun, C.J. The leadership challenge: Building resilient corporate reputations In Handbook on Responsible Leadership and Governance in Global Business; Doh, J.P., Stumpf, S.A., Eds.; Edward Elgar: Cheltenham, UK, 2005; pp. 54-68.

60. Guillamon-Saorin, E.; Kapelko, M.; Stefanou, S.E. Corporate Social Responsibility and Operational Inefficiency: A Dynamic Approach, Open Access. Sustainability 2018, 10, 2277. [CrossRef]

61. Sethi, S.; Martell, T.; Demir, M. Building corporate reputation through corporate social responsibility (CSR) reports: the case of extractive industries. Corp. Reput. Rev. 2016, 19, 219-243. [CrossRef]

62. Miller, K.; Serafeim, G. Chief sustainability officers: Who are they and what do they do? In Leading Sustainable Change; Harvard Business School, Oxford, University Press: Oxford, UK, 2014; Chapter 8; pp. 11-15.

63. Salvioni, D.M.; Gennari, F. Corporate governance, ownership and sustainability. Corp. Ownersh. Control 2016, 13, 606-614. [CrossRef]

64. Salvioni, D.M.; Franzoni, S.; Gennari, F.; Cassano, R. Convergence in corporate governance systems and sustainability culture. Int. J. Bus. Perform. Manag. 2018, 19. [CrossRef]

65. Lankoski, L. Alternative conceptions of sustainability in a business context. J. Clean. Prod. 2016, 139, 847-857. [CrossRef]

66. Mihalciuc, C.C.; Apetri, A.N. The Role of Social and Environmental Information in Assessing the Overall Performance of the Enterprise. In Sustainable Economic Development; Leal Filho, W., Pociovalisteanu, D.M., Al-Amin, A., Eds.; World Sustainability Series; Springer: Cham, Switzerland, 2017.

67. Cosmulese, C.G.; Grosu, V.; Hlaciuc, E. Intangible assets with a high degree of difficulty in estimating their value. Ecoforum 2017, 6, 3.

68. KPMG. Survey of Corporate Responsibility Reporting. 2015. Available online: https://assets.kpmg.com/ content/dam/kpmg/pdf/2015/11/kpmg-international-survey-of-corporate-responsibility-reporting2015.pdf (accessed on 12 September 2018).

69. Burlaud, A.; Niculescu, M. Informația non-financiară: O perspectivă europeană. Audit Financiar 2015, 13, 43-53.

70. GRI 102: General Disclosures 2016. In Consolidated set of GRI Sustainability Reporting Standards (2018). Available online: https:/ /www.globalreporting.org/standards/gri-standards-download-center/ consolidated-set-of-gri-standards / (accessed on 13 September 2018).

71. Sustainability Reporting Guidelines. GRI. 2013. Available online: https://www.globalreporting. org/resourcelibrary/GRIG4-Part1-Reporting-Principles-and-Standard-Disclosures.pdf (accessed on 13 September 2018).

72. International Integrated Reporting Framework. Available online: http:/ /integratedreporting.org/resource/ international-ir-framework/ (accessed on 13 September 2018).

73. Dima, S.;; Farcane, N.; Popa, A. Financial and Non-financial Information in the Framework of Sustainability and Integrated Reporting. Audit Financiar 2015, 2, 21-85.

74. Dragu, I.; Tiron-Tudor, A. New corporate reporting trends. Analysis on the evolution of integrated reporting. Ann. Univ. Oradea Econ. Sci. Ser. 2013, 1, 1221-1229.

75. Botez, D. Raportarea integrată—Sfârșit sau un nou început pentru raportarea financiară? Audit Financiar 2013, 2, 23-35.

76. Ienciu, I.; Popa, I.E.; Ienciu, N. Aspecte privind responsabilitatea socială a entităților din România din perspectiva raportărilor de mediu. Audit Financiar 2013, 6, 31.

77. Zlati, M.L.; Antohi, V.M. Analysis of Economic Efficiency through the Analytical Budgeting Method using Econometric Modelling, Annals of “Dunarea de Jos" University of Galati, Fascicle I. Econ. Appl. Informat. 2018, 72-79. Available online: http://www.eia.feaa.ugal.ro/images/eia/2018_1/Zlati_Antohi.pdf (accessed on 14 September2018). 
78. Antohi, V.M.; Zlati, M.L. The Impact of the Application of the Fiscal Risk Assessment Procedure in Romania, Annals of "Dunarea de Jos" University of Galati, Fascicle I. Econ. Appl. Informat. 2017, 78-86. Available online: http:/ / www.eia.feaa.ugal.ro/images/eia/2017_3/Antohi_Zlati.pdf (accessed on 14 September 2018).

79. Ionescu, R.V.; Moga, L.M.; Antohi, V.M. Modelling of the Technical Progress Impact on the Romanian Agriculture. J. Food Agric. Environ. 2010, 8, 1081-1085, WFL Publisher. Available online: http:/ / world-food. net/download/journals/2010-issue_3_4/26\%283\%29.pdf (accessed on 14 September 2018).

80. Florea, A.M.; Radu, R.I.; Mihai, O.I. The Implications of Information Systems Audit for Financial Statement, Risk in Contemporary Economy; Europlus Publishing House: Galati, Romania, 2015; Volume 2, Number 1; pp. 314-319.

81. Korka, M. Corporate Social Responsibility in Romania: From Theory to Practice. Transit. Stud. Rev. 2005, 12, 47-57. [CrossRef]

82. Berheci, M. Responsabilitatea corporativă și performanțele companiilor multinaționale, în Studii post-doctorale în economie. Post-Doctoral Dissertations, Romanian Academy Publishing House, Bucharest, Romania, 2013.

83. Directive 2014/95/EU of the European Parliament and of the Council of 22 October 2014.EUR-Lex. Available online: https:/ / eur-lex.europa.eu/legal-content/EN/TXT/?uri=CELEX\%3A32014L0095 (accessed on 6 December 2018).

84. European Parlament and the Council. Directive 2013/34/EU on the Annual Financial Statements, Consolidated Financial Statements and Related Reports of Certain Types of Undertakings. 2013. Available online: http:/ / eur-lex.europa.eu/LexUriServ /LexUriServ.do?uri=OJ:L:2013:182:0019:0076:EN: PDF (accessed on 16 September 2018).

85. Bunea, Ș. Mizele divulgării de informații nefinanciare și informații privind diversitatea. De la divulgare voluntară la obligație legală. Economistul Magazine. no. 18.25 May 2015. Available online: http:/ / www.economistul.ro/contabilitate-mizele-divulgarii-de-informatii-nefinanciareside-informatii-privind-diversitatea-a7936/ (accessed on 6 December 2018).

86. Apostol, C. Reflectarea politicii de mediu în situaţiile financiare anuale, Lucrări ştiinţifice, Seria Agronomie. In Ion Ionescu de la Brad; Publishing House: Iaşi, Romania, 2008; Volume 51, pp. 359-362.

87. GREEN PAPER. The EU Corporate Governance Framework. Brussels. 5.4.2011 COM (2011) 164 Final. Available online: http://ec.europa.eu/internal_market/company/docs/modern/com2011-164_en.pdf (accessed on 16 September 2018). 